\title{
The Role of Corporate Social Responsibility in Enhancing Firm Performance from the Perspective of IT Employees in Jordanian Banking Sector: The Mediating Effect of Transformational Leadership
}

\author{
Ra'ed Masa'deh ${ }^{1}$, Ala'aldin Alrowwad ${ }^{2}$, Forat Alkhalafat ${ }^{2}$, Bader Obeidat ${ }^{2} \&$ Shadi Abualoush $^{3}$ \\ ${ }^{1}$ Management Information Systems Department, School of Business, The University of Jordan, Amman, Jordan \\ ${ }^{2}$ School of Business, The University of Jordan, Jordan \\ ${ }^{3}$ Management Information Systems Department, Faculty of Administrative Science and Finance, Irbid National \\ University, Jordan
}

Correspondence: Ra'edMasa'deh, Management Information System Department, School of Business, The University of Jordan, Amman 11942, Jordan. Tel: 962-6535-5000. E-mail: r.masadeh@ju.edu.jo

Received: January 12, 2018 Accepted: May 21, 2018 Online Published: June 15, 2018

doi:10.5539/mas.v12n7p1 URL: https://doi.org/10.5539/mas.v12n7p1

\begin{abstract}
Direct relationship between Corporate Social Responsibility (CSR) and firm performance has been extensively studied by scholars in several majors. The direct examination of this relationship seems to be relatively imprecise since many other variables have indirect influence on this relationship. Therefore, this study takes into considerations Transformational Leadership (TFL) as a probable mediator in the role CSR plays to enhance the firm performanceamong Information Technology (IT) employees in banking sector. Data were collected from IT employees within IT departments from 25 banks in Jordan through a questionnaire survey. 354 valid questionnaires were returned and analyzed using different quantitative techniques. This research finds that CSR has a significant influence on firm performance and three of its dimensions, namely, economic responsibility, ethical responsibility, and discretionary responsibility have a significant effect on firm performance, whereas legal responsibility has no remarkable effect. It also finds that CSR has a positive influence on TFL. Specifically, discretionary responsibility has a significant effect on TFL, whereas other dimensions have no significant contribution to TFL. As well as, it finds that TFL has a positive contribution to the firm performance. Inspirational motivation and individualized consideration have the only remarkable contribution to the firm performance. Finally, it has been revealed that TFL partially mediates the relationship between CSR and firm performance.
\end{abstract}

Keywords: corporate social responsibility, transformational leadership, firm performance, IT employees, Jordanian banks

\section{Introduction}

In today's business environment, there is a growing interest from the public in firms' transparency and credibility regarding the disclosure of such information in order to make a balance between stakeholders' goals (Wang et al., 2015). However, the firms' engagement in business activities that target several stakeholders with diverging or opposing interests requires the commitment to encourage actions that bring economic, legal, ethical, and philanthropic benefits whether to the firms, their shareholders, or other stakeholders (Obeidat et al., 2017). For instance, Aras and Crowther (2008) argued that corporations all over the world shed the light on CSR. This concern stems from the reality that CSR strengthens companies' relations with their environment and lead to better firm performance. Building on this view, plenty of studies were conducted to ensure a positive relationship between CSR and firm performance. Donker et al. (2008) suggested a positive correlation between the engagement in social activities and the firm performance. They also suggested that CSR could be considered as a strategic factor in boosting the firm performance. In addition, while adopting CSR as a strategy can lead to such preferable intangible outcomes as reputation (Schwaiger, 2004), employee satisfaction (Epstein and Roy, 2001), IT implementations (Kateb et al., 2015) or better customer satisfaction, most scholars have focused on the financial measures in addressing the possible linkage between CSR and major organizational outcomes (Mishra and Suar, 2010; Obeidat et al., 2013).

As for organizational leadership, transformational leadership (TFL) has been frequently featured in strategy and 
organizational theory researches. It has been linked to several organizational outcomes. Indeed, little has been done as to whether there is a relationship between CSR and TFL. This research sheds the light on the mediating effect of TFL on the relationship between CSR and firm performance. TFL style is comprised of idealized influence, inspirational motivation, intellectual stimulation, and individualized consideration that all could influence on the behaviors regarding CSR outcomes (Bass and Riggio, 2006; AL-Syaidh and Al-Zu'bi, 2014; Masa'deh et al., 2015; AL-Syaidh et al., 2016). Moreover, Groves and LarRocca (2011) indicated in their research on organizational leadership that such organizational leadership style as TFL could be tied with the followers' behavior and attitudes toward CSR that may lead to desirable organizational outcomes.

Abu-Jarad et al. (2010) postulated that it is crucial for any organization to better understand what factors should be taken into consideration to get better performance. Furthermore, Hond et al. (2014) argued that organizations should be concerned with the interests of their different stakeholders in improving their performance. Therefore, they will be able to gain the benefits throughout the governmental support and regulations, and enhancing its image. Accordingly, the research will throw the light on the concept of CSR as a fundamental strategy that enables firms to enhance their performance and respond to the needs of stakeholders simultaneously. In fact, CSR has become a major concept to be studied by scholars (Saeidi et al., 2015). In a narrower business context, managers who are concerned with putting their firms in a safe haven definitely comprehend the critical role and the outcomes of adapting CSR since they have a vital role in establishing and delineating CSR plan. Based on this view, the study will help clarifying the responsibility of TFL in intervening the relationship between CSR and firm performance, and how leaders with transformational behavior is affected by CSR, and effect on the performance of their companies. Waldman et al. (2006) insisted that TFL is highly engaged in CSR where leaders influence the structure of CSR.

The research relies on the nonfinancial measure to assess the firm performance. For many years, the evaluation process of firms' performance depends solely on the financial indicators that have been criticized for many defects. Moreover, financial measures are not able to differentiate between firms; also, they give deceptive information that is totally opposite of the firms' goals (Tseng and Lee, 2014). Cho (2011) claimed that firms have eliminated the financial indicators in assessing the firm performance as long as they are difficult to be manipulated and monitored because of their nature. On the other hand, compared to other models in assessing CSR performance, Carroll's framework is broad enough to take into consideration other concepts of social responsibility including stakeholder theory and corporate citizenship (Ramasamy and Yeung, 2009). As for the organizational leadership, TFL has been one of the most popular supported leadership theories through the past two decades among scholar (Sosik and Jung, 2011). This research would propose a relationship between CSR and TFL to enhance the organizational performance. In sum, the outcomes of this research can help firms to embed, and extend it CSR behavior to maintain and strengthen the abilities of transformational leaders, which in return would enhance the firm performance and improve the prosperity of our society. Also, the outcomes may aid firms to recruit and train managers who can show the characteristics of TFL.

This paper is organized as follows: the first section sets the context of the need to study the influence of corporate social responsibility on transformational leadership and in turn on firm performance. The next section examines the research conceptual framework and hypotheses. The next section indicates the research methodology, and the final section provides the results and research conclusions.

\section{Research Framework and Hypotheses}

This research was conducted to study the impact of corporate social responsibility on firm performance mediated by transformational leadership in the Jordanian banking sector, specifically through IT departments where these departments are highly important and competitive.

\subsection{Operational Definitions}

Dependent, independent and mediating variables of the study are operationalized as follows.

\subsubsection{Corporate Social Responsibility (The Independent Variable)}

Several scholars from different majors and fields have defined CSR. However, the majority of these definitions claimed that corporations have responsibilities that go beyond making profits and maximizing the wealth of shareholder. The world business council for sustainable development (WBCSD, 1999) defined CSR as "the commitment by organizations to behave ethically and contribute to economic development while improving the quality of life of the workforce, and their families as well as the local community and society at large". This research will adapt a definition developed by Carroll (1999) who defined CSR as "the conduct of business that is economically profitable, law abiding, ethical and social supportive". Furthermore, the researchers will adapt 
Carroll's model for CSR. According to (Carroll, 1999), organizations have four main responsibilities. The following definitions were developed by Wheelen et al. (2015).

Economic Responsibility: responsibilities of organizations are producing valuable goods and services to the community; therefore, they can make profits and maximize the wealth of shareholders.

Legal Responsibility: responsibilities of abiding by the law, engaging in actions without deception or fraud.

Ethical Responsibility: responsibilities of following the values, beliefs, and behavior of a particular society.

Discretionary Responsibility: voluntary commitment assumed by an organization that focuses on such things as improving the life of employees, local community, and the society at large.

\subsubsection{Transformational Leadership (The Mediating Variable)}

TFL was earlier defined by Burns (1978) who defined it as a leadership style that takes place when leader and followers support each other to achieve common goals and high level of morality. Building on this definition, TFL refers in this study as a leadership style that inspires followers to go beyond their own self-interests who is capable of having a profound and extraordinary effect on followers (Robbins and Judge, 2015). TFL is composed of four main dimensions as suggested by Avolio, et al. (1999).

Idealized Influence: Idealized influence is also called charisma and refers to leaders who act as a role model, exert a sense of power and confidence, make high influential decisions, behave according to deeply values and beliefs, and display high morality (Bruch and Walter, 2007).

Inspirational Motivation: Inspirational Motivation refers to leaders who enthusiastically and optimistically create a vision for the future and stimulate similar feelings among followers in the organization (Bi et al., 2012).

Intellectual Stimulation: Intellectual stimulation refers to leaders who support followers to be more innovative and creative by examining the assumptions and using several approaches to solve problems (Limsila and Ogunlana, 2008).

Individualized Consideration: Individualized consideration refers to the leaders' consideration to the followers' capabilities to identify their needs for future development while taking into account their individual differences (Bi et al., 2012).

\subsubsection{Firm Performance (The Dependent Variable)}

Generally speaking, scholars in strategic management have developed several definitions for firm performance (Loshali and Krishnan, 2013). Luxmi (2014) defined firm performance as the actual outcomes produced by an organization compared to its planned outputs. Firm performance in this study refers to the combination of effectiveness and efficiency of individuals, groups, and organization at large (Tseng and Lee, 2014). This research will rely on nonfinancial indicators to assess the firm performance. Therefore, four dimensions will be used to measure the firm performance.

Innovation: Innovation in this study refers to the overall organizational approach to improve value creation by generating and developing new ideas in terms of new products or services, processes and managerial system (Chen et al., 2010).

Reputation: Firm's reputation refers to the stakeholders' impression that reflects their perceptions about the firm's initiatives and the assessments of product and services that firm supplied (Hsu, 2012).

Service Quality: Service quality refers to the overall perceptions of performance the services offered by employees in a particular service shop (Yee et al., 2010).

Employee Satisfaction: Employee satisfaction is defined as the extent to which employees are happy, contended, and fulfilling their desires and needs at their work (Tavakkol and Janani, 2014).

\subsection{Measurement of Variables}

\subsubsection{Corporate Social Responsibility (The Independent Variable)}

Over the last few decades, scholars all over the globe have paid a remarkable attention to CSR where it has become an outstanding concept in literatures (Nejati and Ghasemi, 2012). In spite of the large body of literatures that discussed CSR; Wood (2010) claimed that it is difficult for researchers to conceptualize CSR since it means different things for different people. Therefore, the lack of precise conceptualization has led scholar to diverse CSR (Talaei and Nejati, 2008). Galbreath and Shum (2012) stated that there is no widespread method to measure in order to measure CSR. Some methods rely on collecting primary data while other methods collect secondary data. This study will use Carroll's (1999) model to conceptualized CSR. This model has been frequently used by 
researches and does not rely on secondary data (Saeidi et al., 2015). The instrument developed by Carroll (1999) was developed by Maignan and Ferrell (2001). It consists of four major dimensions: economic, legal, ethical, and discretionary. The instrument contains 14 items, 4 items to measure the economic responsibility, 4 items to measure the legal responsibility, 3 items to measure the ethical responsibility, and 3 items to measure the discretionary responsibility.

Table 1. CSR Measurement

\begin{tabular}{cl}
\hline \multicolumn{1}{c}{ Dimensions } & \multicolumn{1}{c}{ Corporate Social Responsibility } \\
\hline Economic Responsibility & The bank concerns with maximizing the profit. \\
The bank controls its production cost strictly. & The bank plans for the long-term success. \\
The bank always improves its economic performance. & The bank ensures that their employees act within the standards defined by \\
law. & The bank refrains from putting aside their contractual obligations. \\
& The bank refrains from bending the law even this helps improve its \\
performance. & The bank submits to the principles defined by the regulatory system. \\
The bank ensures that the respect of ethical principles has priority over \\
economic performance. \\
The bank is committed to well- defined ethical principles. \\
The bank avoids compromising ethical standards in order to achieve \\
corporate goals. \\
The bank helps to solve social problems. \\
The bank participates in the management of public affairs. \\
The bank plays role in our society that goes beyond the generation of profit.
\end{tabular}

\subsubsection{Transformational Leadership (The Mediating Variable)}

Mediation is the function that variable supposes when it accounts for the linkage between the independent and dependent variable (Baron and Kenny, 1986). Sekaran and Bougie (2016) defined the mediator as a variable that surfaces between the time the independent variable begins operating to affect the dependent variable and the time its influence is felt on the dependent variable. Therefore, the mediator plays two roles. First, it is a dependent variable for the predictor. Second, it is an independent variable for the criterion (Veríssimo and Lacerda, 2015). In this study, TFL would be suggested as a mediator between CSR and firm performance as this style become more important to organizations to enhance its performance as well as to employees in order to achieve a growth and personal satisfaction (Loshali and Krishnan, 2013). Regarding the measurement of TFL, several approaches have been developed to assess TFL. Some approaches use the observation while others rely on conducting an interview. However, this study will use the instrument developed by Avolio et al. (1999). TFL was conceptualized using four dimensions: idealized influence, inspirational motivation, intellectual stimulation, and individualized consideration. 16 items were taken to measure TFL. 4 items to measure idealized influence, 4 items to measure inspirational motivation, 4 items to measure intellectual stimulation, and 4 items to measure individualized consideration.

Table 2. TFL Measurement

\begin{tabular}{|c|c|}
\hline \multicolumn{2}{|r|}{ Transformational Leadership } \\
\hline Dimensions & Items \\
\hline Idealized Influence & $\begin{array}{l}\text { My manager talks to me about his/her most important values and beliefs. } \\
\text { My manager considers the moral and ethical consequences of decisions. } \\
\text { My manager is considered a role model for me. }\end{array}$ \\
\hline & My manager displays a sense of power and confidence. \\
\hline Inspirational & My manager talks optimistically about the future. \\
\hline
\end{tabular}




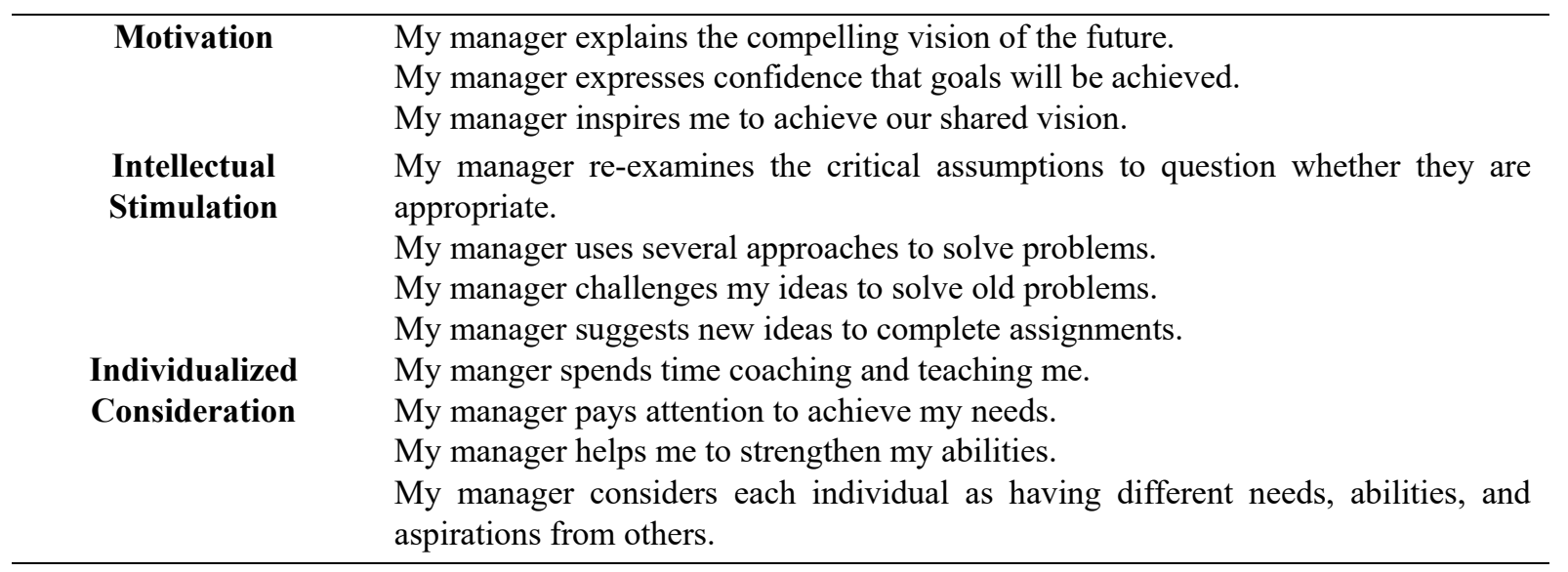

\subsubsection{Firm Performance (The Dependent Variable)}

Nowadays, firms are seeking to take into consideration all changes surrounding them in order to enhance their performance. Regarding the measurement of firm performance, majority of literatures argued that firm performance is difficult to be conceptualized and measured. Conventionally, firms assess their performance using financial indicators. These indicators have been criticized for their short-term horizon and lack of strategic focus (Shahin et al., 2014). As well as, they fail to capture performance from such intangible assets as innovation, quality, or employee satisfaction which become a major source for competitive advantage (Mishra and Suar, 2010). Therefore, nonfinancial indicators should be considered in assessing the firm performance as different stakeholders are important in a business environment to the firm (Alkalha et al., 2012). Firm performance as a sole dependent variable in this research will be assessed by using four dimensions related to the nonfinancial performance: innovation and employee satisfaction as suggested by Kaplan and Norton (2001), service quality as suggested by Kuo (2011), and reputation as suggested by Ariff et al. (2014). 16 items to measure the firm performance, 3 items to innovation adapted from Chen et al. (2010), 5 items to measure the firm's reputation adapted from Petrick (2002), 5 items to measure service quality adapted from Parasuraman et al. (1991), the five items are chosen to be appropriate with the study as suggested by Yee et al. (2010), and 3 items to measure employee satisfaction adapted from (Huang and Rundle-Thiele, 2014).

Table 3. Firm Performance Measurement

Firm Performance

\begin{tabular}{|c|c|}
\hline \multicolumn{2}{|r|}{ Firm Performance } \\
\hline Dimensions & Items \\
\hline Innovation & The bank develops new product or service. \\
\hline & The bank develops its management system. \\
\hline & The company develops the technology it uses (equipment, information systems, and \\
\hline \multirow[t]{5}{*}{ Reputation } & The bank has a good reputation within its industry. \\
\hline & The bank is well respected. \\
\hline & The bank is well thought of for its customers. \\
\hline & The bank has status. \\
\hline & The bank is reputable. \\
\hline \multirow{5}{*}{ Service Quality } & The employees' appearance at the bank is neat. \\
\hline & When the bank promises to provide a particular service at a certain time, it does so. \\
\hline & The bank provides prompt services to customers. \\
\hline & Employees at the bank can be trusted by customers. \\
\hline & The bank understands the needs of its customer. \\
\hline \multirow[t]{3}{*}{ Employee Satisfaction } & I am satisfied with the opportunities my bank provides to interact with others. \\
\hline & I am satisfied with the variety of activities my bank offers. \\
\hline & I do not enjoy my job. \\
\hline
\end{tabular}

Whereas all items were measured using a five-point rating scale, rating from one: "Strongly disagree", two: 
"Disagree", three: "Moderately agree", four: "Agree", to five: "Strongly agree". Research theoretical model is illustrated in figure 1 which clarifies the relationship between study variables.

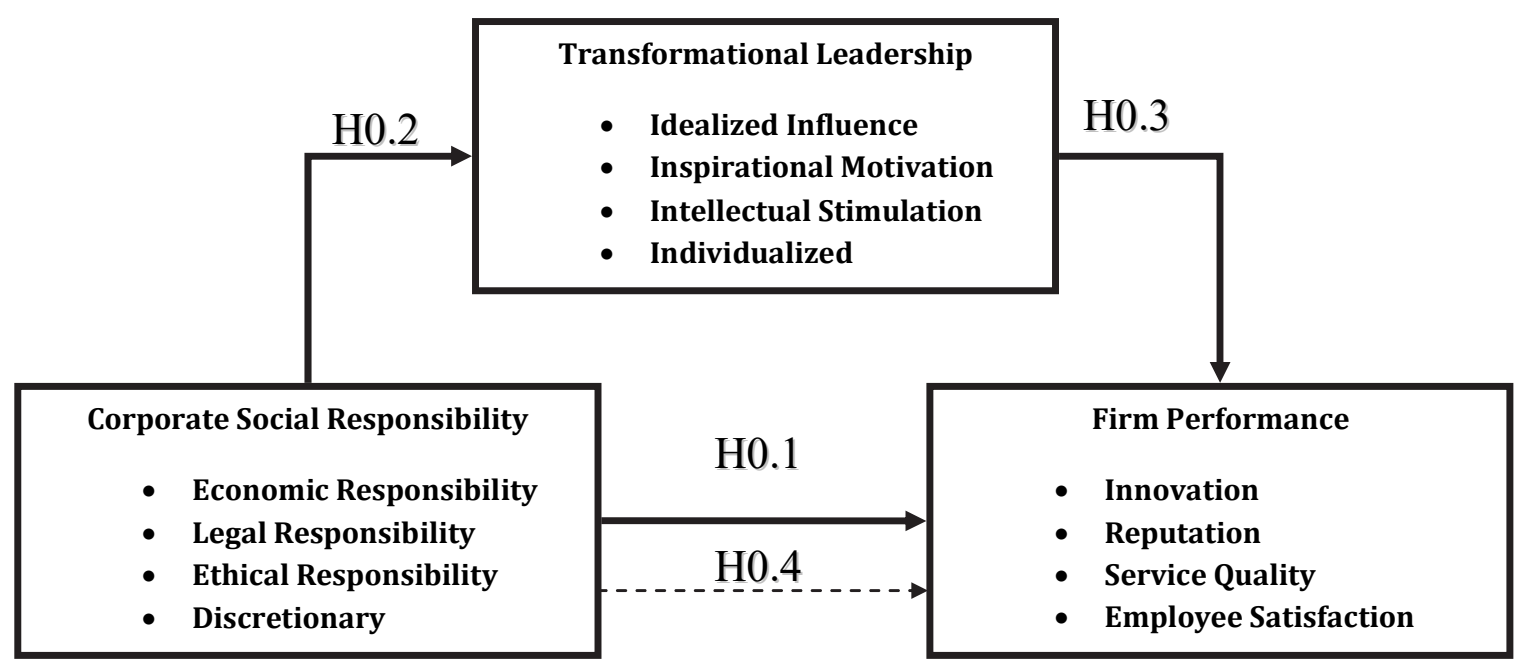

Figure 1. The Research Model

\subsection{Research Hypotheses}

2.3.1 Corporate Social Responsibility and Firm Performance

H01: There is no statistical relationship between Corporate Social responsibility and Firm Performance.

H01.1: There is no statistical relationship between Economic responsibility and Firm Performance.

H01.2: There is no statistical relationship between Legal responsibility and Firm Performance.

H01.3: There is no statistical relationship between Ethical responsibility and Firm Performance.

H01.4: There is no statistical relationship between Discretionary responsibility and Firm Performance.

2.3.2 Corporate Social Responsibility and Transformational Leadership

H02: There is no statistical relationship between Corporate Social responsibility and Transformational Leadership.

H02.1: There is no statistical relationship between Economic Responsibility and Transformational Leadership.

H02.2: There is no statistical relationship between Legal Responsibility and Transformational Leadership.

H02.3: There is no statistical relationship between Ethical Responsibility and Transformational Leadership.

H02.4: There is no statistical relationship between Discretionary Responsibility and Transformational Leadership.

\subsubsection{Transformational Leadership and Firm Performance}

H03: There is no statistical relationship between Transformational Leadership and Firm Performance.

H03.1: There is no statistical relationship between Idealized Influence and Firm Performance.

H03.2: There is no statistical relationship between Inspirational Motivation and Firm Performance.

H03.3: There is no statistical relationship between Intellectual Stimulation and Firm Performance.

H03.4: There is no statistical relationship between Individualized Consideration and Firm Performance.

\subsubsection{Corporate Social Responsibility, Transformational Leadership, and Firm Performance}

H04: The relationship between Corporate Social Responsibility and Firm Performance is not statistically mediated through Transformational Leadership.

\section{Research Methodology}

\subsection{Research Population, Sample, and Data Collection}

The population of this study consists of all employees at all managerial levels working in the 25 banks in Jordan. According to the annual reports for the banks at the end of 2015, it has been reported that the total number of 
employees working in the banks was 20095 employees.

Quota sampling was used to ensure that the various banks that make up the Jordanianbanking sector were adequately represented in the study through the assignment of a quota. According to this, it can be seen in Table 4 the appropriate sample that should be taken from each bank in order to reach the requiredsample size. After determining the quota to be drawn from each bank, the researchers followed simplerandom sampling since the determined number of questionnaires to be distributed to each bank were given to theHR department and distributed at random. In order to determine the appropriate sample size for this research based on the selected population, Sekaran and Bougie (2016) proposed a scientific guideline for sample size decision which was followed in this research. Basedon the table prepared by Sekaran and Bougie (2016), the sample size for this research should be 377 IT Employees given that the population represents the total number of IT employees working in the Jordanian banking sectorwhich is 2449 IT bank employees. However, this paper aimed to collect 500 questionnaires as stated in the abovedetailed table. Researchers gave out 500 questionnaires to the 25 banks and received 354 usable questionnaires. The remaining 146 questionnaires were deemed unusable. The Response rate was calculated and the result was $(354 / 500=70.8 \%)$. The following table provides a description of the number of employees working in the banks in Jordan.

Table 4. Number of Employees Working in the Banks (Source: Association of Banks in Jordan, 2016)

\begin{tabular}{|c|c|c|c|c|c|}
\hline NO. & Name & $\begin{array}{l}\text { Total Number of } \\
\text { Employees }\end{array}$ & $\begin{array}{c}\text { Total } \\
\text { Percentage } \\
\text { of Number } \\
\text { of } \\
\text { Employees } \\
(\%)\end{array}$ & $\begin{array}{c}\text { Total } \\
\text { Number } \\
\text { of IT } \\
\text { Employees }\end{array}$ & $\begin{array}{c}\text { Number of } \\
\text { Questionnaires } \\
\text { Required per } \\
\text { Bank }\end{array}$ \\
\hline 1 & Arab Bank & 2934 & $14.60 \%$ & 330 & 73 \\
\hline 2 & $\begin{array}{l}\text { The Housing Bank for } \\
\text { Trade \& Finance }\end{array}$ & 2363 & $11.76 \%$ & 290 & 59 \\
\hline 3 & Jordan IslamicBank & 2148 & $10.69 \%$ & 281 & 53 \\
\hline 4 & Cairo Amman Bank & 1614 & $8.03 \%$ & 230 & 40 \\
\hline 5 & Bank of Jordan & 1489 & $7.41 \%$ & 180 & 37 \\
\hline 6 & Jordan Ahli Bank & 1416 & $7.05 \%$ & 158 & 35 \\
\hline 7 & Jordan Kuwait Bank & 1100 & $5.47 \%$ & 127 & 27 \\
\hline 8 & Union Bank & 915 & $4.55 \%$ & 112 & 23 \\
\hline 9 & $\begin{array}{c}\text { International ArabIslamic } \\
\text { Bank }\end{array}$ & 852 & $4.24 \%$ & 104 & 21 \\
\hline 10 & $\begin{array}{c}\text { Arab Jordan Investment } \\
\text { Bank }\end{array}$ & 714 & $3.55 \%$ & 103 & 18 \\
\hline 11 & Jordan Commercial Bank & 695 & $3.46 \%$ & 78 & 17 \\
\hline 12 & Capital Bank & 575 & $2.86 \%$ & 59 & 14 \\
\hline 13 & Arab Banking Corp./Jordan & 500 & $2.49 \%$ & 53 & 12 \\
\hline 14 & Invest Bank & 461 & $2.29 \%$ & 42 & 11 \\
\hline 15 & $\begin{array}{c}\text { Jordan DubaiIslamic } \\
\text { Bank(Now: Safwa Bank) }\end{array}$ & 424 & $2.11 \%$ & 42 & 11 \\
\hline 16 & BLOM Bank & 382 & $1.90 \%$ & 41 & 10 \\
\hline 17 & Egyptian Arab Land Bank & 307 & $1.53 \%$ & 39 & 8 \\
\hline 18 & Audi Bank & 269 & $1.34 \%$ & 37 & 7 \\
\hline 19 & $\begin{array}{l}\text { SocieteGenerale de Banque- } \\
\text { Jordan }\end{array}$ & 257 & $1.28 \%$ & 34 & 6 \\
\hline 20 & Al-Rajhi Bank & 248 & $1.23 \%$ & 34 & 6 \\
\hline 21 & Standard CharteredBank & 196 & $0.98 \%$ & 29 & 5 \\
\hline 22 & $\begin{array}{c}\text { National Kuwait Bank- } \\
\text { Jordan }\end{array}$ & 98 & $0.49 \%$ & 21 & 2 \\
\hline 23 & CITI Bank & 66 & $0.33 \%$ & 14 & 1 \\
\hline 24 & National Bank ofAbu Dhabi & 53 & $0.26 \%$ & 8 & 1 \\
\hline 25 & Rafidain Bank & 19 & $0.09 \%$ & 3 & 1 \\
\hline \multicolumn{2}{|c|}{ Total number of employees } & 20095 & $100 \%$ & 2449 & 500 \\
\hline
\end{tabular}




\section{working in the banks}

\subsection{Validity and Reliability}

Validity indicates that it measures the used instrument goodness and suitability in measuring in the study's variables. Whereas the reliability concerned about whether the measurement tool proves on the steadiness and the constancy of the measured concepts, it is also considered as the instrument mirror that reflects its precision and thoroughness (Blumberg et al., 2014; Sekaran and Bougie, 2016).

\subsubsection{Content and Face Validity}

Face validity makes sure that items in the instrument are measuring the right concepts on the face of it (Sekaran and Bougie, 2016). Hair, et al. (2010) suggested that face validity can be established through evaluating the study instrument by a group of experts. Therefore, the researchers have distributed the questionnaire to experts with $\mathrm{PhD}$ qualifications in the University of Jordan and other national universities. Also, the researchers have sent the questionnaire to expert with PhD qualifications in the University of Texas at Arlington (UTA). All comments have been taken into consideration regarding the measurement of variables, and the translation of the questions to the Arabic language.

\subsubsection{Construct Validity}

Construct validity testifies how-well the results of the study obtained by a particular measure fit with the theory around which the test was designed (Sekaran and Bougie, 2016). This form of validity can be established using different ways. One of the major ways to examine the construct validity is factor analysis (Sekaran and Bougie, 2016). Using factor analysis helps to summarize the data so that the linkages among variables can be easily understood (Yong and Pearce, 2013). CFA was used as it determines which measured variable are related to other latent variables (Hair et al., 2010). Hair et al., (2010) suggested that the standardized regression for the exogenous variable should be greater than 0.4 .

To conduct the CFA, Chi-square $\left(\mathrm{X}^{2}\right)$ is usedto examine whether the distribution of variables are different from one another. Then, the degrees of freedom (DF) that represent the number of values that have the freedom to vary are defined. Furthermore, the harmonization level will be calculated using the minimum discrepancy level $\left(\mathrm{X}^{2} / \mathrm{DF}\right)$. According to Arbuckle (2008), the harmonization level should be ranged from 1 to 5. Once the harmonization level is calculated, the quality of this harmonization (GFI) should be defined. Arbuckle (2008) argued that the quality level should be near to 1 . In this regard, the values of comparative fit index (CFI) should be determined. Finally, the root mean of square error of approximation (RMSEA) and the value on normed fit index (NFI) are determined. RMSEA should be close to zero, and NFI should be close to 1 . The following figures present the main findings of CFA using (SPSS AMOS). Thereafter, the standardized regression weight will be shown. Hair et al. (2010) postulated that the values of standardized regression weight should be greater than 0.4 . 


\subsubsection{Corporate Social Responsibility (The Independent Variable)}
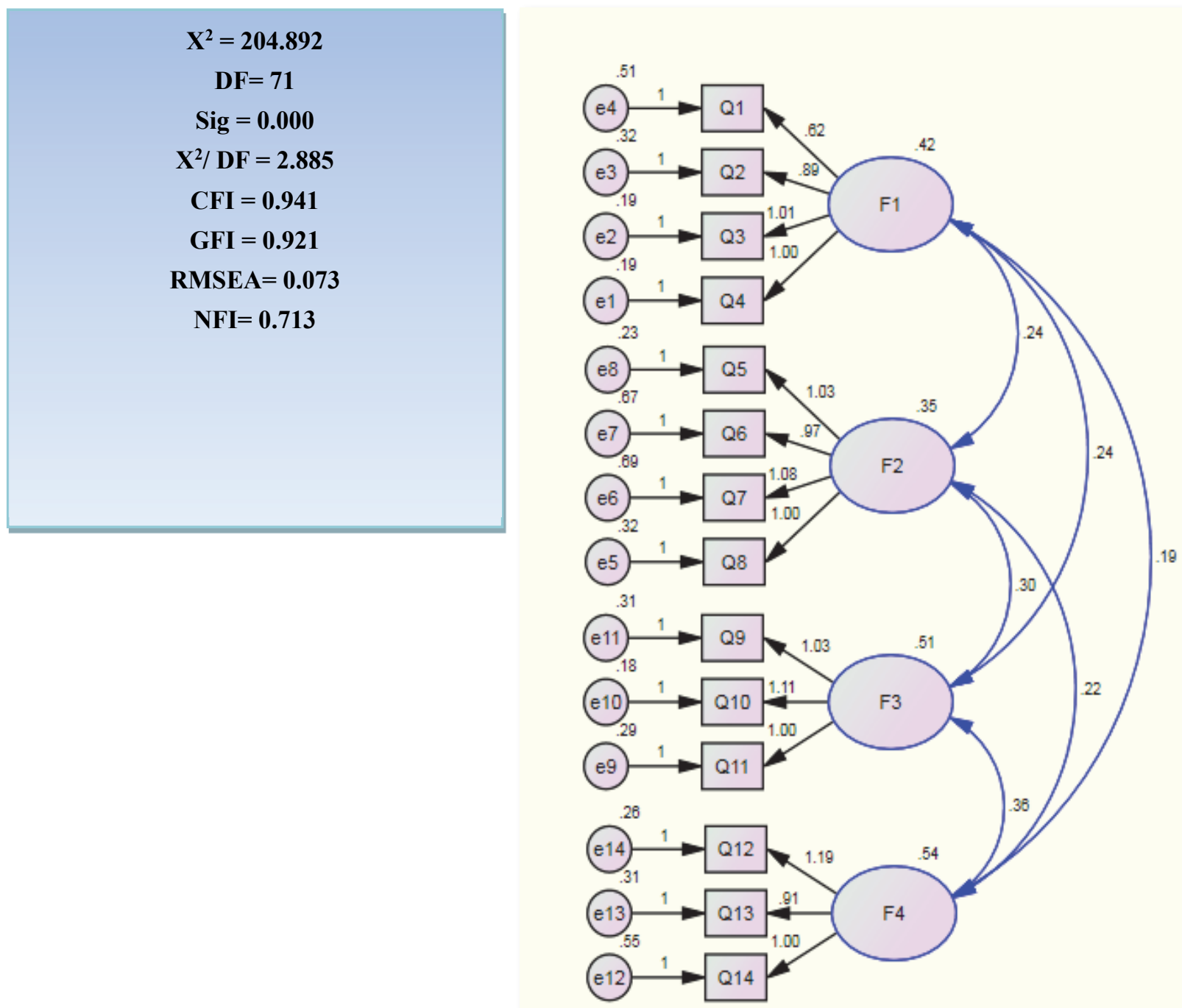

Figure 2. CFA of CSR

Noticeably all values in the above figures are statistically confirmed. $X^{2}$ is 204.892 . Thisvalue is significant at ( $\alpha$ $\leq .05) . \mathrm{X}^{2} / \mathrm{DF}$ equal to 2.885 which indicate a good harmonization level. Regarding the quality of the harmonization (GFI) represents a high level of quality 0.921 . Regarding the value of $\mathrm{CFI}=0.941$, this value is closer to one. Moreover, the approximated error in CSR is 0.073 which is close to zero, and NFI is 0.0713 and closed to 1 . The following table presents the values of standardized regression weight for the questions used to measure CSR:

Table 5. Standardized Regression Weights of CSR

\begin{tabular}{cccc}
\hline Question & & Dimension & Estimate \\
\hline Q1 & $<---$ & & 0.487 \\
Q2 & $<---$ & Economic Responsibility & 0.715 \\
Q3 & $<---$ & & 0.832 \\
Q4 & $<---$ & & 0.828 \\
Q5 & $<---$ & & 0.787 \\
\hline
\end{tabular}




\begin{tabular}{cccc}
\hline Q6 & $<---$ & Legal responsibility & 0.575 \\
Q7 & $<---$ & & 0.611 \\
Q8 & $<---$ & & 0.722 \\
Q9 & $<---$ & & 0.798 \\
Q10 & $<---$ & Ethical Responsibility & 0.883 \\
Q11 & $<---$ & & 0.797 \\
Q12 & $<---$ & & 0.862 \\
Q13 & $<---$ & Discretionary Responsibility & 0.767 \\
Q14 & $<---$ & & 0.702 \\
\hline
\end{tabular}

It is evident that all above values are statistically accepted. Hair et al. (2010) argued that values of standardized regression weight should be higher than 0.4 .

3.2.2.2 Firm Performance (The Dependent Variable)
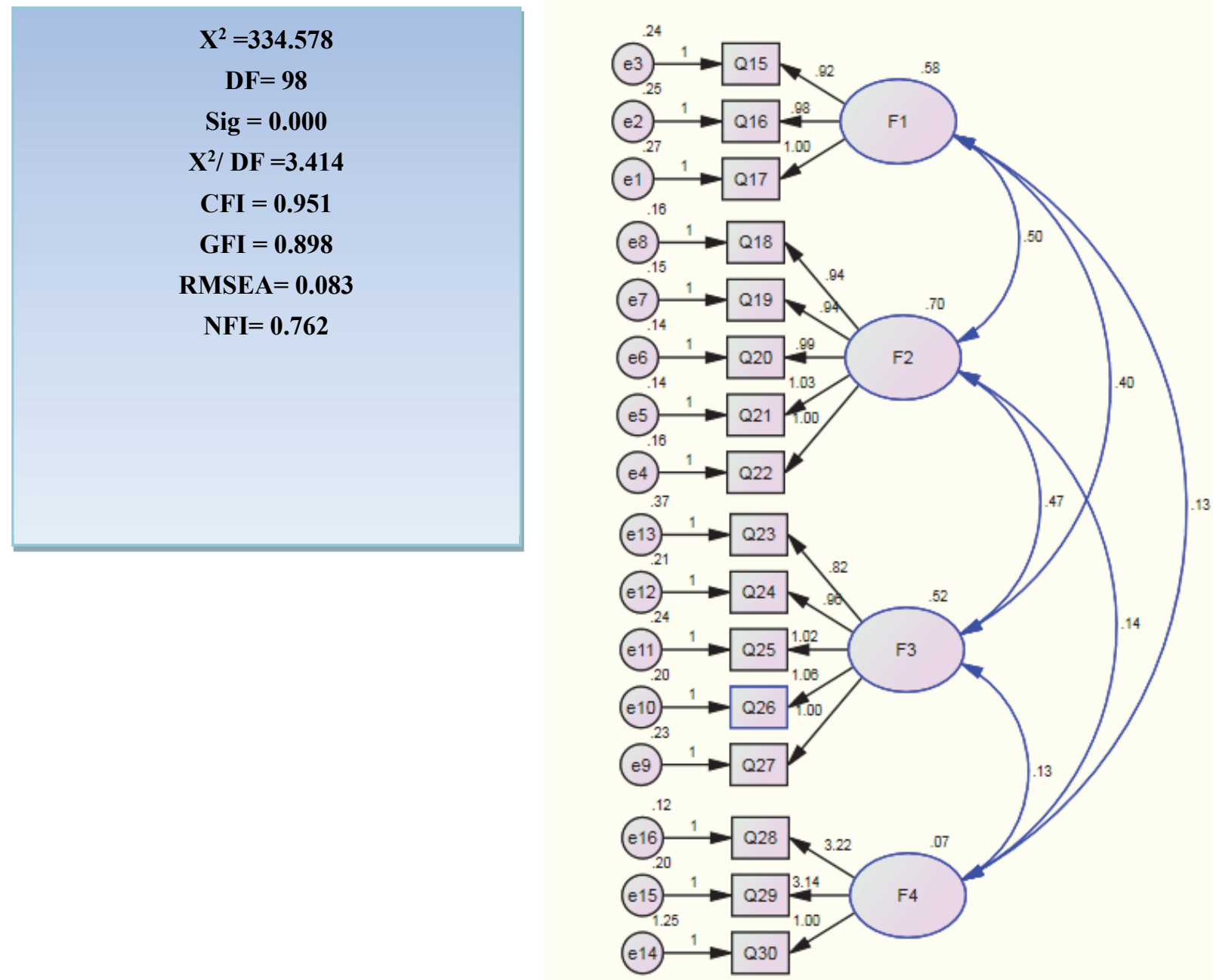

Figure 3. CFA of Firm Performance

Briefly, all values are statistically accepted. At $(\alpha \leq .05), \mathrm{X}^{2}$ is 334.578 which are significantly confirmed. $\mathrm{X}^{2} / \mathrm{DF}$ equal to 3.414. Therefore, it could be claimed that the harmonization level is good. The quality of this harmonization (GFI) is 0.898 which indicated a high level of quality. CFI is 0.951 and close to 1 . Finally, RMSEA is 0.083 and NFI is 0.0762 . Both values are statistically confirmed. Accordingly, the values of standardized regression weight will be presented for the questions used to assess the firm performance. All the following values 
are higher than 0.4 . Therefore, it can be argued that they are within the acceptance range.

Table 6. Standadized Regression Weights of Firm Performance

\begin{tabular}{cccc}
\hline Question & & Dimension & Estimate \\
\hline Q15 & $<---$ & & 0.815 \\
Q16 & $<---$ & Innovation & 0.826 \\
Q17 & $<---$ & & 0.826 \\
Q18 & $<---$ & & 0.890 \\
Q19 & $<---$ & Reputation & 0.895 \\
Q20 & $<---$ & & 0.911 \\
Q21 & $<---$ & & 0.915 \\
Q22 & $<---$ & & 0.904 \\
Q23 & $<---$ & & 0.701 \\
Q24 & $<---$ & Service Quality & 0.834 \\
Q25 & $<---$ & & 0.833 \\
& & & 0.862 \\
Q26 & $<---$ & & 0.833 \\
Q27 & $<---$ & & 0.929 \\
Q28 & $<---$ & & 0.828 \\
Q29 & $<---$ & Employee Satisfaction & 0.533 \\
Q30 & $<---$ & &
\end{tabular}

3.2.2.3 Transformational Leadership (The Mediating Variable)
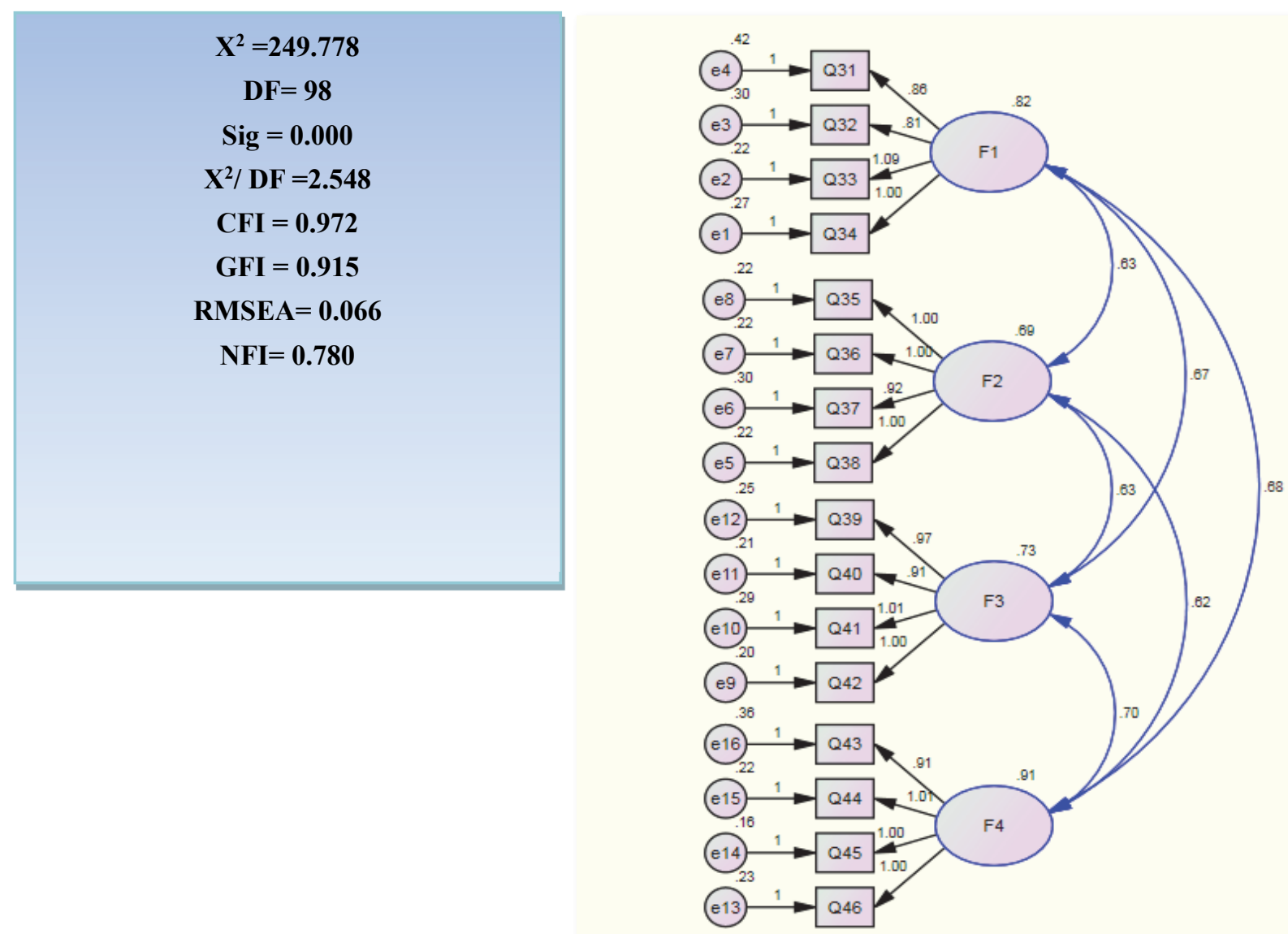

Figure 4. CFA of TFL 
Generally speaking, the value of $\mathrm{X}^{2}$ is significantly confirmed at $(\alpha \leq .05)$. Dividing $\mathrm{X}^{2}$ by DF shows a good harmonization level. The estimated quality level of this harmonization is 0.915 . RMSEA is 0.066 which is closed to zero where as NFI is 0.780 and closed to 1 . The following table presents the estimated values of standardized regression weight for the questions used to assess TFL:

Table 7. Standardized Regression Weights of TFL

\begin{tabular}{cccc}
\hline Question & & Dimension & Estimate \\
\hline Q31 & $<---$ & & 0.769 \\
Q32 & $<---$ & Idealized Influence & 0.803 \\
Q33 & $<---$ & & 0.902 \\
Q34 & $<---$ & & 0.867 \\
Q35 & $<---$ & Inspirational Motivation & 0.873 \\
Q36 & $<---$ & & 0.869 \\
Q37 & $<---$ & & 0.815 \\
Q38 & $<---$ & & 0.871 \\
Q39 & $<---$ & & 0.858 \\
Q40 & $<---$ & Intellectual Stimulation & 0.862 \\
Q41 & $<---$ & & 0.849 \\
& & & 0.886 \\
Q42 & $<---$ & & 0.823 \\
Q43 & $<---$ & & 0.898 \\
Q44 & $<---$ & Individualized Consideration & 0.924 \\
Q45 & $<---$ & & 0.894 \\
Q46 & $<---$ & &
\end{tabular}

All values in the standardized regression weight are greater than 0.4 . Therefore, it can be postulated that the validity of questions used to assess TFL are established. As well as, the validity of the research model is established.

\subsection{Reliability of Scales}

In order to measure the consistency and homogeneity of items that belong to the same concept in the questionnaire, the internal consistency measure of inter-item consistency reliability was tested using Cronbach's alpha. Cronbach's alpha for the study sample are shown in Table 8 below.

Table 8. Cronbach's Alpha of the Main Variables

\begin{tabular}{ccc}
\hline Dimension & Number of Items & Cronbach's Alpha Values \\
\hline Corporate Social Responsibility & 14 & 0.879 \\
Firm Performance & 16 & 0.946 \\
Transformational Leadership & 16 & 0.966 \\
\hline
\end{tabular}

Obviously, the Cronbach's Alpha Values for the main variables are greater than 0.6 which indicates a high degree of reliability (Hair et al., 2010).

Table 9. Reliability Statistics

\begin{tabular}{ccc}
\hline Study Construct & Number of Items & Cronbach's Alpha Values \\
\hline CSR & $\mathbf{1 4}$ & $\mathbf{0 . 8 7 9}$ \\
ER & 4 & 0.812 \\
LR & 4 & 0.764 \\
ETR & 3 & 0.865 \\
DR & 3 & 0.815 \\
FP & $\mathbf{1 6}$ & $\mathbf{0 . 9 4 6}$ \\
INN & 3 & 0.862 \\
CR & 5 & 0.956 \\
SQ & 5 & 0.906 \\
\hline
\end{tabular}




\begin{tabular}{ccc}
\hline ES & 3 & 0.643 \\
TFL & $\mathbf{1 6}$ & $\mathbf{0 . 9 6 6}$ \\
II & 4 & 0.900 \\
IM & 4 & 0.917 \\
IS & 4 & 0.920 \\
IC & 4 & 0.935 \\
\hline
\end{tabular}

As the Cronbach's alpha values are greater than the acceptable level of 0.70 (Sekaran and Bougie, 2016). As shown in Table 9, the variables and all of the items representing them can be said to exhibit excellent internal consistency and can therefore be considered reliable.

\subsection{Normality Test}

Normality test will be conducted to assure that the sample represents the entire population. To do this, skewness and kurtosis test will be performed. West et al. (1995) argued that if values of skewness (between 2 to -2 ), and valued of kurtosis (between 7 to -7), then the study sample is considered to be normally distributed.

Table 10. Skewness and Kurtosis Test

\begin{tabular}{ccccc}
\hline Dimension & \multicolumn{2}{c}{ Skewness } & \multicolumn{2}{c}{ Kurtosis } \\
\cline { 2 - 5 } & Statistic & Std. Error & Statistic & Std. Error \\
ER & -0.781 & 0.13 & 0.612 & 0.259 \\
LR & -0.242 & 0.13 & -0.523 & 0.259 \\
ETR & -0.645 & 0.13 & 0.325 & 0.259 \\
DR & -0.159 & 0.13 & -0.297 & 0.259 \\
CSR & -0.433 & 0.13 & 0.375 & 0.259 \\
INN & -0.789 & 0.13 & 0.074 & 0.259 \\
CR & -0.806 & 0.13 & 0.372 & 0.259 \\
SQ & -0.633 & 0.13 & 0.219 & 0.259 \\
ES & -0.169 & 0.13 & -0.228 & 0.259 \\
FP & -0.833 & 0.13 & 0.251 & 0.259 \\
II & -0.541 & 0.13 & 0.722 & 0.259 \\
IM & -0.626 & 0.13 & 0.386 & 0.259 \\
IS & -0.617 & 0.13 & 0.452 & 0.259 \\
IC & -0.522 & 0.13 & 0.147 & 0.259 \\
TFL & -0.6 & 0.13 & 0.935 & 0.259 \\
\hline
\end{tabular}

Obviously, the previous table shows that the values of skewness range between (2 to -2$)$. Also, the values of kurtosis range between ( 7 to -7$)$. These findings indicate that the sample is normally distributed. Therefore, the parametric test will be conducted.

\section{Research Results}

\subsection{Demographic Characteristics of Respondents}

Demographic data provides the main attributes of the participating respondents which is included in the questionnaire instrument. These attributes include basic information about the respondents like gender, age, qualifications, job experience, and job position in banks. Table 11 shows the main attributes of the participating respondents.

Table 11. The Attributes of Respondents

\begin{tabular}{|c|c|c|}
\hline Respondents' characteristics & Frequency & Percentages \\
\hline \multicolumn{3}{|c|}{ Gender } \\
\hline Male & 210 & 59.3 \\
\hline Female & 144 & 40.7 \\
\hline \multicolumn{3}{|c|}{ Age } \\
\hline 20 - less than 25 & 58 & 16.4 \\
\hline 25 - less than 30 & 87 & 24.6 \\
\hline
\end{tabular}




\begin{tabular}{|c|c|c|}
\hline 30 - less than 35 & 116 & 32.7 \\
\hline 35 and above & 93 & 26.3 \\
\hline \multicolumn{3}{|c|}{ Qualifications } \\
\hline Bachelor & 259 & 73.2 \\
\hline Diploma & 18 & 5.1 \\
\hline Master & 72 & 20.3 \\
\hline $\mathrm{PhD}$ & 5 & 1.4 \\
\hline \multicolumn{3}{|c|}{ Job Experience } \\
\hline Less than 3 years & 64 & 18.1 \\
\hline 3 - less than 6 & 87 & 24.6 \\
\hline 6 - less than 9 & 73 & 20.6 \\
\hline 9 and above & 130 & 36.7 \\
\hline \multicolumn{3}{|c|}{ Job Position } \\
\hline Manager & 44 & 12.4 \\
\hline Assistant Manager & 42 & 11.9 \\
\hline Department Head & 75 & 21.2 \\
\hline Employee & 193 & 54.5 \\
\hline
\end{tabular}

Based on the previous table, the findings show that $59.3 \%$ of respondents were males and $40.7 \%$ females. This indicator means that majority of employees working in the banks in Jordan are female. However, these findings cannot be generalized. According to ABJ (2015), the percentage of female working in the banking sector in Jordan has been increased by $10 \%$ to reach $34.2 \%$. This ratio is considered as high compared with other sectors in Jordan. Regarding the age of respondents, the findings represent that $32.7 \%$ of respondents belong to the age group 30 less than 35 , followed by $26.3 \%$ belong to age group 35 and above, $24.6 \%$ belong to 25 - less than 30 , and $16.4 \%$ belong to 20-less than 25. This indicates there is a mix of age groups in the banks in Jordan. Also, it could be clearly observed that these findings are consistent with other respondents' characteristics.

As for the qualification, $73.2 \%$ of respondents hold the bachelor's degree which is considered as a high ratio, followed by $20.3 \%$ hold the master's degree, $5.1 \%$ hold the diploma's degree, and $1.4 \%$ hold the $\mathrm{PhD}$ certificate. These findings indicate that the minimum level of qualification to work in the banks is the diploma's degree. However, it could be argued that banks in Jordan seek to hire employees hold higher qualification as bachelor or master degree. In terms of job experience, $36 \% .7$ of respondents have job experience more than 9 years, followed by $24.6 \%$ have experience between 3-less than 6 years, 20.6\% have experience between 6 and less than 3 years, and $18.1 \%$ have less than 3 years. These findings indicated that the banks seek to achieve a human resource strategy to attract and maintain experienced employees. Finally, $54.5 \%$ of respondents are employees, followed by $21.2 \%$ department heads, $12.4 \%$ are managers, and $11.9 \%$ are assistant managers. These results indicate that banks in Jordan seek to build an organic structure with a wide span of control.

\subsection{Hypotheses Testing}

The following equations were formulated based on the hypotheses:

1. $\quad \mathrm{FP}=\alpha+\beta 1 \mathrm{ER}+\beta 2 \mathrm{LR}+\beta 3 \mathrm{ETR}+\beta 4 \mathrm{DR}+€$.

2. $\mathrm{TFL}=\alpha+\beta 1 \mathrm{ER}+\beta 2 \mathrm{LR}+\beta 3 \mathrm{ETR}+\beta 4 \mathrm{DR}+€$.

3. $\mathrm{FP}=\alpha+\beta 1 \mathrm{II}+\beta 2 \mathrm{IM}+\beta 3 \mathrm{IS}+\beta 4 \mathrm{IC}+€$.

4. $\quad \mathrm{FP}=\alpha+\beta 1 \mathrm{CSR}+\beta 2 \mathrm{TFL}+€$.

4.2.1 Corporate Social Responsibility and Firm Performance

H01: There is no statistical relationship between Corporate Social responsibility and Firm Performance.

H01.1: There is no statistical relationship between Economic responsibility and Firm Performance.

H01.2: There is no statistical relationship between Legal responsibility and Firm Performance.

H01.3: There is no statistical relationship between Ethical responsibility and Firm Performance.

H01.4: There is no statistical relationship between Discretionary responsibility and Firm Performance. 
Table 1. Multiple Regression of the First Hypothesis

\begin{tabular}{ccccccccc}
\hline & $\mathbf{R}$ & $\mathbf{R}^{2}$ & Adjusted R $^{2}$ & F-value & Sig & & & \\
\cline { 2 - 6 } & 0.664 & 0.441 & 0.435 & 68.938 & 0.000 & t & Sig & Beta \\
$\begin{array}{c}\text { Constant } \\
\text { Economic } \\
\text { Responsibility }\end{array}$ & & & & & & 3.729 & 0.000 & 0.736 \\
$\begin{array}{c}\text { Legal } \\
\text { Responsibility } \\
\quad \text { Ethical }\end{array}$ & & & & 7.358 & 0.000 & 0.350 \\
$\begin{array}{c}\text { Responsibility } \\
\text { Discretionary } \\
\text { Responsibility }\end{array}$ & & & & 1.577 & 0.116 & 0.076 \\
\hline
\end{tabular}

Firm performance is the dependent variable.

The findings above indicate that multiple correlation coefficient $\mathrm{R}=0.664$. This means a positive correlation between CSR and firm performance. $\mathrm{R}^{2}=0.441$ which means that dimensions used to assess CSR explained $44.1 \%$ of the variation in the firm performance. Moreover, it can be noticed that the value of adjusted $R^{2}=0.435$ is very close to the value of $\mathrm{R}^{2}$. If the adjusted $\mathrm{R}^{2}$ is excluded from $\mathrm{R}^{2}(0.441-0.435)=0.006$. This little shrinking of 0.006 means that if the model has been fitted with the entire population, the higher variance in the outcome will be 0.006 . The probability of F-Value is 68.938 indicates the combination of economic responsibility, legal responsibility, ethical responsibility, and discretionary responsibility has a significant effect on firm performance at $(\alpha \leq 0.05)$. Accordingly, the first main hypothesis is rejected. Regarding the effect of economic responsibility on firm performance, the significant value of economic responsibility at $(\alpha \leq 0.05)$ is 0.000 . The t-calculated is 7.358 and higher than the value of t-tabulated 1.96. This means that the banks' economic responsibility has a significant effect on their performance. Therefore, the first-sub hypothesis is rejected at $(\alpha \leq 0.05)$.

Referring to the previous table, the significant value of legal responsibility is 0.116 . This means it is not significant at $(\alpha \leq 0.05)$. Furthermore, the t-calculated of legal responsibility is 1.557 . This value is lower than $t$-tabulated 1.96; this indicates that legal responsibility has no significant effect on firm performance at $(\alpha \leq 0.05)$. Therefore, the null hypothesis is accepted. In terms of the ethical responsibility, the significant value of this dimension is 0.000 . This value indicates that ethical responsibility is significant at $(\alpha \leq 0.05)$. The t-calculated is 4.485 . Therefore, the researchers reject the null hypothesis and accept the alternate hypothesis because the value of $t$ calculated is higher than the value of t-tabulated. Discretionary responsibility has a significant value of 0.000 and the t-calculated is 4.045 . Theses both values indicate the discretionary responsibility has a significant effect on the firm performance at $(\alpha \leq 0.05)$. Accordingly, null hypothesis is rejected. The following table summarizes the results of testing the sub-hypotheses for the first main hypothesis.

Table 2. The Results of Testing the First Null Hypotheses

\begin{tabular}{lc}
\hline Ho1.1: There is no statistical relationship between Economic responsibility and Firm & Rejected \\
Performance. & \\
\hline Ho1.2: There is no statistical relationship between Legal responsibility and Firm & Accepted \\
Performance. & Rejected \\
\hline Ho1.3: There is no statistical relationship between Ethical responsibility and Firm & \\
\hline Herformance. & Rejected \\
Performance. &
\end{tabular}

As a consequence, the formula of the first hypothesis is:

$\mathrm{FP}=(0.736)+\mathrm{ER}(0.350)+\mathrm{LR}(0.076)+\mathrm{ETR}(0.208)+\mathrm{DR}(4.045)+€$.

\subsubsection{Corporate Social Responsibility and Transformational Leadership}

H02: There is no statistical relationship between Corporate Social responsibility and Transformational Leadership.

H02.1: There is no statistical relationship between Economic Responsibility and Transformational Leadership. 
H02.2: There is no statistical relationship between Legal Responsibility and Transformational Leadership.

H02.3: There is no statistical relationship between Ethical Responsibility and Transformational Leadership.

H02.4: There is no statistical relationship between Discretionary Responsibility and Transformational Leadership.

Table 3. Multiple Regression of the Second Hypothesis

\begin{tabular}{ccccccccc}
\hline & $\mathbf{R}$ & $\mathbf{R}^{2}$ & Adjusted R $^{2}$ & F-value & Sig & & & \\
\cline { 2 - 6 } & 0.539 & 0.290 & 0.282 & 35.647 & 0.000 & $\mathbf{t}$ & Sig & Beta \\
Constant & & & & & & 3.721 & 0.000 & 1.007 \\
$\begin{array}{c}\text { Economic } \\
\text { Responsibility } \\
\quad \text { Legal }\end{array}$ & & & & & 1.690 & 0.092 & 0.110 \\
$\begin{array}{c}\text { Responsibility } \\
\text { Ethical }\end{array}$ & & & & & 1.313 & 0.190 & 0.086 \\
$\begin{array}{c}\text { Responsibility } \\
\text { Discretionary } \\
\text { Responsibility }\end{array}$ & & & & & 1.418 & 0.157 & 0.090 \\
\hline
\end{tabular}

TFL is the dependent variable.

The multiple correlation coefficient $\mathrm{R}=0.539$, which means there is a positive relationship between CSR and TFL. This relationship suggests that both variables move in the same direction. $\mathrm{R}^{2}=0.290$ presents the amount of variation in TFL that has been explained by CSR. It is noticed that the value of adjusted $R^{2}$ is 0.282 and very close to the value of $\mathrm{R}^{2}$. Using (ANOVA) allows the researchers to statistically test the main null hypothesis. The findings show that $\mathrm{F}$-value $=35.647$. This value is significant at $(\alpha \leq 0.05)$. Therefore, as it has been proposed, CSR as a firm strategy plays a significant role in enhancing TFL. The coefficient table presents that Economic responsibility has a significant value of 0.092 . The t-calculated of economic responsibility is 1.690 . Accordingly, the null hypothesis is accepted. Regarding the other dimensions of CSR, the significant values of legal responsibility, ethical responsibility, and discretionary responsibility are $0.190,0.157$, and 0.000 respectively. Based on these findings, the following decisions can be made regarding the second hypotheses.

Table 4. The Results of Testing the Second Null Hypotheses

\begin{tabular}{|c|c|}
\hline $\begin{array}{l}\text { Ho2.1: There is no statistical relationship between Economic responsibility and } \\
\text { Transformational Leadership }\end{array}$ & Accepted \\
\hline $\begin{array}{l}\text { Ho2.2: There is no statistical relationship between Legal responsibility and } \\
\text { Transformational Leadership. }\end{array}$ & Accepted \\
\hline $\begin{array}{l}\mathbf{H}_{02.3:} \text { There is no statistical relationship between Ethical responsibility and } \\
\text { Transformational Leadership. }\end{array}$ & Accepted \\
\hline $\begin{array}{l}\text { Ho2.4: There is no statistical relationship between Discretionary responsibility and } \\
\text { Transformational Leadership. }\end{array}$ & Rejected \\
\hline
\end{tabular}

The formula of the second hypothesis as follows:

$\mathrm{TFL}=(1.007)+\operatorname{ER}(0.110)+\mathrm{LR}(0.086)+\operatorname{ETR}(0.090)+\mathrm{DR}(0.395)+€$.

It has been observed that economic, legal, and ethical responsibility have no significant effect on TFL. To better analysis, the researchers tend to use the backward regression to investigate which of the previous variables have caused the problems. The following tables present the findings of backward regression:

Table 5. The Summary of Backward Regression

\begin{tabular}{ccccc}
\hline \multicolumn{5}{c}{ Model Summary } \\
\hline Model & R & R Square & Adjusted R Square & Std. Error of the Estimate \\
\hline 1 & .539 & .290 & .282 & .691 \\
\hline 2 & .535 & .287 & .280 & .692 \\
\hline
\end{tabular}


Table 6. ANOVA of the Two Models for CSR

\begin{tabular}{|c|c|c|c|c|c|c|}
\hline \multicolumn{7}{|c|}{ ANOVA } \\
\hline \multicolumn{2}{|l|}{ Model } & $\begin{array}{c}\text { Sum of } \\
\text { Squares }\end{array}$ & DF & $\begin{array}{l}\text { Mean } \\
\text { Square }\end{array}$ & $\mathbf{F}$ & Sig. \\
\hline \multirow[t]{3}{*}{1} & Regression & 68.084 & 4 & 17.021 & 35.647 & .000 \\
\hline & Residual & 166.641 & 349 & .477 & & \\
\hline & Total & 234.725 & 353 & & & \\
\hline \multirow[t]{3}{*}{2} & Regression & 67.261 & 3 & 22.420 & 46.859 & .000 \\
\hline & Residual & 167.464 & 350 & .478 & & \\
\hline & Total & 234.725 & 353 & & & \\
\hline
\end{tabular}

Generally speaking, the above tables provide evidence the model becomes significant when the legal responsibility excluded. Statistically speaking, Table 16 indicates that $\mathrm{R}=0.539$ with the presence of legal responsibility. The absence of legal responsibility makes $\mathrm{R}=0.535$. As well as. The presence of legal responsibility in the model can explain $29 \%$ of the variation in TFL, whereas the absence of legal responsibility makes $\mathrm{R}^{2}=28.7 \%$. This is because the legal responsibility can enhance the overall relationship between CSR and TFL. However, ANOVA in Table 17 indicates that the sig-value of ANOVA table for the model two is 0.000 at F-value 46.859 and it is significant at $(\alpha \leq 0.05)$ and it is higher than the first model.

Table 7. Coefficient Values Using Backward Regression

\begin{tabular}{|c|c|c|c|c|c|c|}
\hline \multicolumn{7}{|c|}{ Coefficients } \\
\hline \multirow[t]{2}{*}{ Model } & & \multicolumn{2}{|c|}{$\begin{array}{l}\text { Un-standardized } \\
\text { Coefficients }\end{array}$} & \multirow{2}{*}{$\begin{array}{c}\text { Standardized } \\
\text { Coefficients } \\
\text { Beta }\end{array}$} & \multirow[t]{2}{*}{$t$} & \multirow[t]{2}{*}{ Sig. } \\
\hline & & B & Std. Error & & & \\
\hline \multirow[t]{5}{*}{1} & (Constant) & 1.007 & .271 & & 3.721 & .000 \\
\hline & ER & .110 & .065 & .087 & 1.690 & .092 \\
\hline & LR & .086 & .066 & .074 & 1.313 & .190 \\
\hline & ETR & .090 & .064 & .089 & 1.418 & .157 \\
\hline & DR & .395 & .055 & .406 & 7.234 & .000 \\
\hline \multirow[t]{4}{*}{2} & (Constant) & 1.106 & .260 & & 4.246 & .000 \\
\hline & ER & .134 & .063 & . 106. & 2.144 & .033 \\
\hline & ETR & .121 & .059. & .119. & 2.027 & .043 \\
\hline & DR & . 401 & .054 & .412 & 7.376 & .000 \\
\hline
\end{tabular}

Table 8. The Summary of Excluded Variable Using Backward Regression

\begin{tabular}{|c|c|c|c|c|c|c|}
\hline \multicolumn{7}{|c|}{ Excluded Variables } \\
\hline & & Beta In & $\mathbf{t}$ & Sig. & Partial Correlation & Co-linearity Statistics \\
\hline 2 & LR & .074 & 1.313 & .190 & .070 & .632 \\
\hline
\end{tabular}

The Coefficient table indicated that only discretionary responsibility has a significant effect on TFL. However, in the absence of legal responsibility, all independent variables have a significant effect on TFL. The researchers thought that this is a co-linearity diagnostics problem, but we previously conducted this test and we found no problem. Accordingly, the researchers think that this situation might be attributed to the multi measures of CSR. Therefore, the researcher recommends the future studies to use another dimension than (LR).

4.2.3 Transformational Leadership and Firm Performance

H03: There is no statistical relationship between Transformational Leadership and Firm Performance.

H03.1: There is no statistical relationship between Idealized Influence and Firm Performance.

H03.2: There is no statistical relationship between Inspirational Motivation and Firm Performance. 
H03.3: There is no statistical relationship between Intellectual Stimulation and Firm Performance.

H03.4: There is no statistical relationship between Individualized Consideration and Firm Performance.

Table 9. Multiple Regression of the Third Hypothesis

\begin{tabular}{|c|c|c|c|c|c|c|c|c|}
\hline & $\mathbf{R}$ & $\mathbf{R}^{2}$ & Adjusted $\mathbf{R}^{2}$ & F-value & Sig & & & \\
\hline & 0.562 & 0.316 & 0.308 & 40.348 & 0.000 & $\mathbf{t}$ & Sig & Beta \\
\hline Constant & & & & & & 16.484 & 0.000 & 2.203 \\
\hline $\begin{array}{l}\text { Idealized } \\
\text { Influence }\end{array}$ & & & & & & 1.707 & 0.089 & 0.102 \\
\hline $\begin{array}{c}\text { Inspirational } \\
\text { Motivation }\end{array}$ & & & & & & 2.153 & 0.032 & 0.138 \\
\hline $\begin{array}{l}\text { Intellectual } \\
\text { Stimulation }\end{array}$ & & & & & & 1.440 & 0.151 & 0.104 \\
\hline $\begin{array}{l}\text { Individualized } \\
\text { Consideration }\end{array}$ & & & & & & 2.232 & 0.026 & 0.119 \\
\hline
\end{tabular}

Firm performance is the dependent variable.

Statistically Speaking, the multiple correlation coefficient $\mathrm{R}=0.562$ which indicates that TFL and firm performance move in the same direction. The value of $\mathrm{R}^{2}=0.316$ shows the amount of variation in firm performance that has been explained using TFL. Furthermore, the value of adjusted $R^{2}=0.308$ is very close to the value of $R^{2}$. This means if the entire population has participated in this study, the amount of variance will be reduced by 0.008 . As it can be noticed that F-value is 40.348 at $(\alpha \leq 0.05)$, hence, the third null hypothesis will be rejected. Referring to the coefficient table, significant values for the idealized influence, inspirational motivation, intellectual stimulation, and idealized influence are $0.089,0.032,0.151$, and 0.026 . The values of t-calculated are 1.707, 2.153, 1.440, and 2.232 respectively. Accordingly, the following decisions should be made regarding the third sub-hypotheses:

Table 10. The Results of Testing the Third Null Hypotheses

H03.1: There is no statistical relationship between Idealized Influence and Firm Accepted Performance.

H03.2: There is no statistical relationship between Inspirational Motivation and Firm Rejected

Performance.

H03.3: There is no statistical relationship between Intellectual Stimulation and Firm Accepted

Performance.

H03.4: There is no statistical relationship between Individualized Consideration and Firm Rejected

Performance.

The formula of the third hypothesis as follows:

$\mathrm{FP}=(2.203)+\mathrm{II}(0.102)+\mathrm{IM}(0.138)+\mathrm{IS}(0.104)+\mathrm{IC}(0.119)+€$.

In general, TFL has a significant effect on firm performance. The findings above indicate that idealized influence and intellectual stimulation have no significant effect on firm performance. To investigate which variable has caused the problem, backward regression has been conducted.

Table 11. The Summary of Backward Regression

\begin{tabular}{ccccc}
\hline & & & Model Summary & \\
\hline Model & R & R Square & Adjusted R Square & Std. Error of the Estimate \\
1 & .562 & .316 & .308 & .557 \\
2 & .559 & .312 & .306 & .558 \\
\hline
\end{tabular}


Table 12. ANOVA of the Two Models for TFL

\begin{tabular}{|c|c|c|c|c|c|c|}
\hline \multicolumn{7}{|c|}{ ANOVA } \\
\hline Model & & $\begin{array}{c}\text { Sum of } \\
\text { Squares }\end{array}$ & DF & $\begin{array}{c}\text { Mean } \\
\text { Square }\end{array}$ & $\mathbf{F}$ & Sig. \\
\hline \multirow[t]{3}{*}{1} & Regression & 50.154 & 4 & 12.539 & 40.348 & .000 \\
\hline & Residual & 108.454 & 349 & .311 & & \\
\hline & Total & 158.608 & 353 & & & \\
\hline \multirow[t]{3}{*}{2} & Regression & 67.261 & 3 & 16.503 & 52.944 & .000 \\
\hline & Residual & 167.464 & 350 & .312 & & \\
\hline & Total & 234.725 & 353 & & & \\
\hline
\end{tabular}

In the first model, the overall correlation between TFL and firm performance $\mathrm{R}=0.562$, whereas the overall correlation in the second model $\mathrm{R}=0.559$. The Value $\mathrm{R}^{2}$ in the two models is relatively close but higher in the first model. This is because the presences of all variables used to measure TFL. However, ANOVA shows that the sigvalue of ANOVA for the model two is 0.000 at F-value 52.944 and it is significant at $(\alpha \leq 0.05)$ and it is higher than the first model. Accordingly, the following tables will present which variable has caused the problem.

Table 13. Coefficient Values Using Backward Regression

\begin{tabular}{|c|c|c|c|c|c|c|}
\hline \multicolumn{7}{|c|}{ Coefficients } \\
\hline \multirow[t]{2}{*}{ Mode } & & \multicolumn{2}{|c|}{$\begin{array}{l}\text { Un-standardized } \\
\text { Coefficients }\end{array}$} & \multirow{2}{*}{$\begin{array}{c}\text { Standardize } \\
\text { d } \\
\text { Coefficients } \\
\text { Beta }\end{array}$} & \multirow[t]{2}{*}{$\mathbf{t}$} & \multirow[t]{2}{*}{ Sig. } \\
\hline & & B & Std. Error & & & \\
\hline \multirow[t]{5}{*}{1} & (Constant) & 2.203 & .134 & & 16.484 & .000 \\
\hline & II & .102 & .060 & .136 & 1.707 & .089 \\
\hline & IM & .139 & .064 & .176 & 2.153 & .032 \\
\hline & IS & .104 & .072 & .135 & 1.440 & .151 \\
\hline & $\mathrm{IC}$ & .119 & .053 & .172 & 2.232 & .026 \\
\hline \multirow[t]{4}{*}{2} & (Constant) & 2.236 & .132 & & 16.953 & .000 \\
\hline & II & .128 & .057 & .171 & 2.245 & .025 \\
\hline & IM & .178 & .058 & .226 & 3.052 & .002 \\
\hline & $\mathrm{IC}$ & .151 & .049 & .218 & 3.104 & .002 \\
\hline
\end{tabular}

Table 14. The Summary of Excluded Variable Using Backward Regression

\begin{tabular}{lcccccc}
\hline Model & Beta In & $\mathbf{t}$ & Sig. & Partial Correlation & $\begin{array}{c}\text { Co-linearity Statistics } \\
\text { Tolerance }\end{array}$ \\
2 & & & & & .223 \\
\hline
\end{tabular}

Based on the coefficient table, idealized influence and inspirational motivation have no significant effect on the firm performance. However, excluding intellectual stimulation from the first model makes the values of tcalculated higher than 1.96 .

4.2.4 Corporate Social Responsibility, Transformational Leadership, and Firm Performance

H04: The relationship between Corporate Social Responsibility and Firm Performance is not statistically mediated by Transformational Leadership.

To examine the mediating role of TFL in the relationship between CSR and firm performance, path analysis for mediation will be used as suggested by Baron and Kenny (1986). This analysis will be conducted through two stages. First, the direct impact of CSR on firm performance in the absence of TFL will be established. Second, the indirect impact of CSR on firm performance in the presence of TFL will be conducted. To better understanding, the effect of CSR on firm performance will be investigated with the absence of TFL. This effect should be statistically significant. Then, the effect of CSR on firm performance will be investigated with the presence of TFL. To determine the level of mediation effect, if the effect of CSR on firm performance is significant reduced, then, 
TFL is completely mediating the relationship between CSR and TFL. On the same hand, if the effect of CSR is reduced but not significant, Then, TFL is partially mediating the relationship between CSR and firm performance. The effect of CSR on firm performance is statistically explained below:

Table 15. The Path Analysis of CSR, TFL, and Firm Performance

\begin{tabular}{|c|c|c|c|c|}
\hline \multicolumn{5}{|c|}{ CSR $\rightarrow$ TFL (Path A) } \\
\hline & Coefficient & $\mathrm{SE}$ & $\mathrm{t}$ & $\mathrm{P}$ \\
\hline TFL & 0.7159 & 0.657 & 10.8905 & 0.0000 \\
\hline \multicolumn{5}{|c|}{ TFL $\rightarrow$ FP (Path B) } \\
\hline TFL & 0.2607 & 0.0361 & 7.2242 & 0.0000 \\
\hline \multicolumn{5}{|c|}{ CSR $\rightarrow$ FP (Path C) } \\
\hline CSR & 0.7584 & 0.0476 & 15.9216 & 0.0000 \\
\hline \multicolumn{5}{|c|}{$\mathrm{CSR} \rightarrow \mathrm{TFL} \rightarrow \mathrm{FP}$ (Path D) } \\
\hline CSR & 0.5718 & 0.0515 & 11.1104 & 0.0000 \\
\hline
\end{tabular}

The findings above show the path of the relationship among CSR, TFL, and firm performance. It has been found that CSR has a significant effect on TFL where the coefficient value is 0.7159 . This can be seen at Path (A). Regarding the relationship between TFL and firm performance, it can be argued that TFL has a significant effect on firm performance where the coefficient value is 0.2607 . This can be seen at Path (B). However, in order to determine whether TFL has a mediating role in the relationship between CSR and firm performance, the following rules must be met:

1. The effect of CSR on firm performance must be significant

2. The strength of CSR in predicting firm performance must be reduced.

3. The strength of CSR in predicting firm performance must be significant in the presence of TFL.

Accordingly, the above table represents that CSR has a significant effect on firm performance where the coefficient value is 0.7584 (Path C). Furthermore, this relationship is still significant but reduced in the presence of TFL. Therefore, it can be postulated that TFL partially mediates the relationship between CSR and firm performance (Path D). The following table summarizes the study model:

Table 16. The Model Summary

\begin{tabular}{cccccc}
\hline $\mathbf{R}^{\mathbf{2}}$ & Adjusted R & F-Value & DF1 & DF2 & P \\
\hline 0.4939 & 0.4910 & 171.2757 & 2.0000 & 351.0000 & 0.0000 \\
\hline
\end{tabular}

\section{Conclusion}

This research aimed at building on previous literatures to study the role of CSR in enhancing the firm performance through the mediating effect of TFLamong IT employees in banking sector. Another important goal of this research was to be the first in investigating the relationship among CSR, TFL, and firm performance. Moreover, the research posited that formulating an effective CSR strategy can be considered as an incubator to strengthen and entrench leaders with transformational behaviors. Therefore, TFL will more likely influence on firm performance. Analyzing the data collected from 354 employees at all managerial levels in the Jordanian banks reveals that CSR significantly effects on firm performance. Thus, it can be postulated that articulating an effective CSR strategy is positively associated with a high level of performance in the Jordanian banks. These findings are consistent with other findings obtained in other researches where CSR as a firm strategy has a positive influence on the firm performance (e.g. Simpson and Kohers, 2002; Mackey et al., 2007; Obeidat, 2016). The premise behind this association can be attributed to the fact that firms have established relationships with different stakeholders who have different interests (Erhemjamts et al., 2013). These interests can be satisfied by building a comprehensive corporate strategy that takes into consideration the social implication to address and balance the competing interests of different stakeholders. According to Orlitzky et al. (2011), separating the bilateral relationships and prioritizing the multilateral stakeholders' interests can achieve higher firm performance. Therefore, the alignment between social goals and business goal can be made by considering CSR a strategic tool to enhance the firm performance (Mishra and Suar, 2010). 
Indeed, it has been observed that legal responsibility influences firm performance. However, this effect is not statistically significant at $(\alpha \leq 0.05)$. Theoretically speaking, it could be concluded that despite the compliance of Jordanian banks with the legal laws and regulations, the legislators cannot create an effective legal atmosphere that can be used as a double-edged sword where it can protect the rights of customers and supports firms to enhance their performance. Remarkable efforts have been exerted to investigate the linkage between CSR and TFL. This research revealed a positive association between CSR and TFL. The findings of this research are consistent with the other researches that investigated the relationship between CSR and TFL (e.g. Turner et al., 2002; Guarnieri and Kao, 2008; Ghosh, 2016). The reason behind this relationship is that TFL encourages followers to seek mutual vision in order to create value for different stakeholders (Pradhan and Pradhan, 2015). Moreover, TFL is predicated on deontological ethics and concentrates on the morality of means rather than the end and outcomes (Groves and LaRocca, 2011). Therefore, it can be claimed that CSR is a strategic incubator to make TFL more consistent and stronger.

Testing the hypotheses regarding the relationship between CSR and TFL indicates that excluding the legal responsibility as a central component of the CSR enables the economic responsibility and ethical responsibility to significantly effect on TFL. This also indicates that legislator should create CSR agenda that is well voiced and explained. Therefore, firms can understand their duties and how the engagement in CSR would enhance their performance. However, regardless the presences of legal responsibility, discretionary responsibility still have a significant influence on TFL. As such it is possible that legal responsibility cannot minimize the role of discretionary responsibility in shaping TFL and firm performance. The result of analysis has found that TFL has a significant positive influence on firm performance. This finding is supported by several studies conducted to investigate the linkage between TFL and firm performance (e.g. Obiwuru et al. 2011; Groves and LaRocca, 2011; Orabi, 2016; Obeidat; 2016). The premise behind this finding is that in a dynamic environment, firms are seeking to continuously enhance their performance. Also, they are seeking efficient ways to outperform competitors. Therefore, TFL as an intangible asset can be merged with other organizational assets to achieve higher performance (Obiwuru, 2011). Indeed, firms pay more attention on TFL due to the fact the TFL has the ability to help followers develop their skills and knowledge to face different circumstances (Shahhosseini et al., 2013). Furthermore, it creates an organizational atmosphere that is characterized by high levels of trust, challenging, inspiration, and individualized consideration (Pradhan and Pradhan, 2015).

Regarding the relationship among CSR, TFL, and firm performance, it has been found that TFL is partially mediating the relationship between CSR and firm performance. In essence, the utilization of CSR as a firm strategy can embed and strengthen the presence of leaders with transformational behavior (Guarnieri and Kao, 2008). Furthermore, building an effective CSR strategy toward morality and ethics has a positive influence on TFL (Prabhakar et al., 2016). Therefore, embedding CSR strategy reinforces TFL who in turn achieve better organizational performance.

\subsection{Contribution of the Study}

This research was built on previous literatures regarding the role of CSR in enhancing the firm performance. Indeed, previous researches were conducted in different countries with different cultures and different work settings. Chapple and Moon (2005) stated that CSR is considered as a western phenomenon due to the presence of strong institutions, clear standards, and strict laws which are relatively weak in developing countries. This research was conducted in the banks in Jordan since limited efforts have been exerted to investigate the role of CSR in the banking sector in Jordan, specifically among IT employees in Jordanian banking sector. Typically, researchers have concentrated on studying the relationship between CSR and firms' financial performance. This research paid much attention in exploring the linkage between CSR and firms' nonfinancial performance. Using nonfinancial measures enables firms to better predict their long run performance, and assess their progress toward achieving their strategic goals and objectives (Kaplan and Norton, 2001).

Moreover, it has been argued that the relationship between CSR and firm performance cannot be completely reliable (Alafi and Hasoneh, 2012). Therefore, it has been suggested that the nature of this association might be influence by several mediating or moderating variables. Drawing on this view, the study examined the mediating role of TFL in the relationship between CSR and firm performance. Christensen, et al. (2014) stated that TFL is associated with social justice, morality, and other socially responsible outcomes. They also stated the leadership theories provide a foundation for emerging work on CSR and TFL.

\subsection{Limitations and Recommendations}

Like any other researches, this research encountered several limitations. There are certain limitations that should be acknowledged. Generally speaking, respondents on the questionnaire may have overemphasized the positive 
aspect of CSR, TFL, and firm performance in their firms. Furthermore, it has been observed a limited number of respondents who were not willing to answer questions in a survey related their firms. However, inconsistent and illogical responses have been treated in a professional manner as suggested by (Sekaran and Bougie, 2016). This research was conducted in the banks in Jordanamong IT employees. The findings of the study cannot be generalized to the whole banking sector since there are various departments have not participated in this study. Therefore, it is recommended to investigate the relationship among CSR, TFL, and firm performance in the whole departments of the banking sector to better representative of the entire populations. As well as, it is recommended to conduct this research in such industries as telecommunication, pharmaceutical, construction, or educational sector.

In a narrower context, this paper follows Carroll (1999) as one of the commonly used approach to measure CSR. Also, it follows Avolio et al. (1999) as the most commonly method to assess TFL. Indeed, it has been noticed that the relationship between CSR, and TFL should be extensively studied. Thus, it proposed to use other measurement techniques mentioned in the literature review to study the relationship between CSR, and TFL. It should also be noted that using the financial indicators along with the nonfinancial indicators is encouraged to eliminate the possibility of subjectivity since the financial performance can be assessed using the financial statements and other accompanying notes that are more objective compared to the nonfinancial measures (Wang et al., 2015). Another limitation is the sampling design chosen to select the elements from the entire population. Quota sampling is characterized by quick, and efficiency. However, this sampling design is the least reliable of all sampling designs regarding the generalizability. To overcome this limitation, it is recommended to use other probability sampling techniques as stratified random sampling to obtain more useful and generalized findings. Moreover, using more advance statistical techniques as hierarchical regression or structural equation modeling is encouraged in future researches.

Practically speaking, there should be solid efforts toward greater CSR by Jordanian firms. Almost since the financial crisis that took a place at the end of 2007, Jordanian society is suffering from disequilibrium circumstances caused by both public and private sector. This disequilibrium leads to higher unemployment rate, inflation, and decrease in the purchasing power. Moreover, the inability to engage in entrepreneurial activities indicates how the institutional, social and economic gaps have worsened recently. Therefore, this research recommends banks to get fully engaged in CSR strategies to soften the overall economic circumstances. Indeed, building a comprehensive CSR strategy helps harmonize the society and resolve the social disparities that have increased remarkably in recent years. The engagement in CSR strategies is inevitable under the current economic adversities. On the same hand, CSR as a firm strategy can improve the firms' profitability in the long run. It also enhances their reputation that may give them a competitive advantage from stakeholders' perspectives. In so doing, firms can attract skilled and talented employees, good suppliers and customers, and benefit from government incentives for engaging in CSR activities. Accordingly, Jordan needs CSR agenda that is well voiced and committed to enhance the life of society. Establishing this agenda is not an easy task but it is one worth undertaking.

\section{Funding}

The author(s) received no financial support for the research, authorship, and/or publication of this article.

\section{Acknowledgments}

The authors are grateful to the senior editor, associate editor, and three anonymous reviewers for their invaluableguidance and insightful comments. Also, we thank all bank managers; head of the IT departments, and all ITemployees participated in this research for their collaboration.

\section{References}

Abu-Jarad, I., Yusof, N., \& Nikbin, D. (2010). A Review Paper on Organizational Culture and Organizational Performance. International Journal of Business and Social Science, 1(3).

Alafi, K., \& Hasoneh, A. (2012). Corporate Social Responsibility Associated with Customer Satisfaction and Financial Performance: A Case study with Housing Banks in Jordan. International Journal of Humanities and Social Science, 2(15), 102-115.

Alkalha, Z., Al-Zu'bi, Z., Al-Dmour, H., Alshurideh, M., \& Masa'deh, R. (2012). Investigating the Effects of Human Resource Policies on Organizational Performance: An Empirical Study on Commercial Banks Operating in Jordan. European Journal of Economics, Finance and Administrative Sciences Administrative Sciences, 51, 44-64.

AL-Syaidh, N., \& Al-Zu'bi, Z. (2014). Transformational Leadership and its Impact on the Effectiveness of Employees' Behavior in the Public and Private Jordanian Hospitals. Jordan Journal of Business 
Administration, 11(1), 23-57.

AL-Syaidh, N., Al-Lozi, M., \& AlHarrasi, J. (2016). Transformational Leadership and its Role on the Effectiveness of Employees' Behavior: A Theoretical Study. Journal of Business \& Management (COES\&RJ-JBM), 4(1), 14-35.

Aras, G., \& Crowther, D. (2008). Governance and Sustainability: An Investigation into the Relationship between Corporate Governance and Corporate Sustainability. Management Decision, 46(3), 433-448.

Arbuckle, J. (2008). Amos 17.0 User's Guide. SPSS Inc.

Ariff, M., Zakuan, N., Tajudin, M., Ahmad, A., Ishak, N., \& Ismail, K. (2014). A Framework for Risk Management Practices and Organizational Performance in Higher Education. Review of Integrative Business and Economics Research, 3(2), 422.

Association of Banks in Jordan (ABJ). (2016). Development of the Jordanian Banking Sector 2003-2012. Retrieved from http://www.abj.org.jo/enus/developmentofthejordanianbankingsector.aspx

Avolio, B., Bass, B., \& Jung, D. (1999). Re-Examining the Components of Transformational and Transactional Leadership Using the Multifactor Leadership. Journal of Occupational and Organizational Psychology, 72(4), 441-462.

Baron, R., \& Kenny, D. (1986). The Moderator-Mediator Variable Distinction in Social Psychological Research: Conceptual, Strategic, and Statistical Considerations. Journal of Personality and Social Psychology, 51(6), 1173-1182.

Bass, B., \& Riggio, R. (2006). Transformational Leadership. Psychology Press.

Bi, L., Ehrich, J., \& Ehrich, L. (2012). Confucius as Transformational Leader: Lessons for ESL Leadership. International Journal of Educational Management, 26(4), 391-402.

Blumberg, B., Cooper, D., \& Schindler, P. (2014). Business Research Methods (4th ed). United States: McGraw Hill Higher Education.

Bruch, H., \& Walter, F. (2007). Leadership in Context: Investigating Hierarchical Impacts on Transformational Leadership. Leadership and Organization Development Journal, 28(8), 710-726.

Burns, J. M. (1978). Leadership. New Yorker: Harper and Row.

Carroll, A. (1999). Corporate Social Responsibility: Evolution of a Definitional Construct. Business and Society, 38(3), 268-295.

Chapple, W., \& Moon, J. (2005). Corporate Social Responsibility (CSR) in Asia a Seven-Country Study of CSR Website Reporting. Business and Society, 44(4), 415-441.

Chen, C., Huang, J., \& Hsiao, Y. (2010). Knowledge Management and Innovativeness: The Role of Organizational Climate and Structure. International Journal of Manpower, 31(8), 848-870.

Cho, T. (2011). Knowledge Management Capabilities and Organizational Performance: An Investigation into the Effects of Knowledge Infrastructure and Processes on Organizational Performance. Unpublished Doctoral Dissertation, University of Illinois at Urbana-Champaign, Illinois, USA.

Christensen, L., Mackey, A., \& Whetten, D. (2014). Taking Responsibility for Corporate Social Responsibility: The Role of Leaders in Creating, Implementing, Sustaining, or Avoiding Socially Responsible firmBehaviors. The Academy of Management Perspectives, 28(2), 164-178.

Donker, H., Poff, D., \& Zahir, S. (2008). Corporate Values, Codes of Ethics, and Firm Performance: A Look at the Canadian Context. Journal of Business Ethics, 82(3), 527-537.

Epstein, M., \& Roy, M. (2001). Sustainability in Action: Identifying and Measuring the Key Performance Drivers. Long Range Planning, 34(5), 585-604.

Erhemjamts, O., Li, Q., \& Venkateswaran, A. (2013). Corporate Social Responsibility and its Impact on Firms' Investment Policy, Organizational Structure, and Performance. Journal of Business Ethics, 118(2), 395-412.

Galbreath, J., \& Shum, P. (2012). Do Customer Satisfaction and Reputation Mediate the CSR-FP Link? Evidence from Australia. Australian Journal of Management, 37(2), 211-229.

Ghosh, K. (2016). Can Moral Development Lead to Upward Influence Behaviour? The Mediating Role of Transformational Leadership in an Empirical Inquiry. International Journal of Indian Culture and Business Management, 13(4), 541-562. 
Groves, K., \& LaRocca, M. (2011). An Empirical Study of Leader Ethical Values, Transformational and Transactional Leadership, and Follower Attitudes toward Corporate Social Responsibility. Journal of Business Ethics, 103(4), 511-528.

Guarnieri, R., \& Kao, T. (2008). Leadership and CSR-A Perfect Match: How Top Companies for Leaders Utilize CSR as a Competitive Advantage. People and Strategy, 31(3), 34.

Hair, J., Black, W., Babin, B., \& Anderson, R. (2010). Multivariate Data Analysis (7thed). New Jersey: Pearson Education, Inc.

Hond, F., Rehbein, K., Bakker, F., \& Lankveld, H. (2014). Playing on Two Chessboards: Reputation Effects between Corporate Social Responsibility (CSR) and Corporate Political Activity (CPA). Journal of Management Studies, 51(5), 790-813.

Hsu, K. (2012). The Advertising Effects of Corporate Social Responsibility on Corporate Reputation and Brand Equity: Evidence from the Life Insurance Industry in Taiwan. Journal of business ethics, 109(2), 189-201.

Huang, Y., \& Rundle-Thiele, S. (2014). The Moderating Effect of Cultural Congruence on the Internal Marketing Practice and Employee Satisfaction Relationship: An Empirical Examination of Australian and Taiwanese Born Tourism Employees. Tourism Management, 42, 196-206.

Kaplan, R., \& Norton, D. (2001). Transforming the Balanced Scorecard from Performance Measurement to Strategic Management: Part I. Accounting Horizons, 15(1), 87-104.

Kateb, M., Swies, R., Obeidat, B., \& Maqableh, M. (2015). An Investigation on the Critical Factors of Information System Implementation in Jordanian Information Technology Companies. European Journal of Business and Management, 7(36), 11-28.

Kuo, T. (2011). How to Improve Organizational Performance through Learning and Knowledge? International Journal of Manpower, 32, 581-603.

Limsila, K., \& Ogunlana, S. (2008). Linking Personal Competencies with Transformational Leadership Style Evidence from the Construction Industry in Thailand. Journal of Construction in Developing Countries, 13(1), 27-50.

Loshali, S., \& Krishnan, V. (2013). Strategic Human Resource Management and Firm Performance: Mediating Role of Transformational Leadership. Journal of Strategic Human Resource Management, 2(1), 9.

Luxmi, M. (2014). Organizational Learning Act as a Mediator between the Relationship of Knowledge Management and Organizational Performance. Management and Labour Studies, 39(1), 31-41.

Mackey, A., Mackey, T., \& Barney, J. (2007). Corporate Social Responsibility and Firm Performance: Investor Preferences and Corporate Strategies. Academy of Management Review, 32(3), 817-835.

Maignan, I., \& Ferrell, O. (2001). Antecedents and Benefits of Corporate Citizenship: An Investigation of French Businesses. Journal of Business Research, 51(1), 37-51.

Masa'deh, R., Obeidat, B., Zyod, D., \& Gharaibeh, A. (2015). The Associations among Transformational Leadership, Transactional Leadership, Knowledge Sharing, Job Performance, and Firm Performance: A Theoretical Model. Journal of Social Sciences (COES\&RJ-JSS), 4(2), 848-866.

Mishra, S., \& Suar, D. (2010). Does Corporate Social Responsibility Influence Firm Performance of Indian Companies? Journal of Business Ethics, 95(4), 571-601.

Nejati, M., \& Ghasemi, S. (2012). Corporate Social Responsibility in Iran from the Perspective of Employees. Social Responsibility Journal, 8(4), 578-588.

Obeidat, B. (2016). Exploring the Relationship between Corporate Social Responsibility, Employee Engagement, and Organizational Performance: The Case of Jordanian Mobile Telecommunication Companies. International Journal of Communications, Network and System Sciences, 9(09), 361.

Obeidat, B., El-Rimawi, S., Maqableh, M., \& Al-Jarrah, I. (2013). Evaluating the Profitability of the Islamic Banks in Jordan. European Journal of Economics, Finance and Administrative Sciences, 56, 27-36.

Obeidat, B., Tarhini, A., \& Aqqad, N. (2017). The Impact of Intellectual Capital on Innovation via the Mediating Role of Knowledge Management: A Structural Equation Modeling Approach. International Journal of Knowledge Management Studies, 8(3/4), 273-298.

Obiwuru, T., Okwu, A., Akpa, V., \& Nwankwere, I. (2011). Effects of Leadership Style on Organizational Performance: A Survey of Selected Small Scale Enterprises in Ikosi-Ketu Council Development Area of 
Lagos State, Nigeria. Australian Journal of Business and Management Research, 1(7), 100.

Orabi, T. (2016). The Impact of Transformational Leadership Style on Organizational Performance: Evidence from Jordan. International Journal of Human Resource Studies, 6(2), 89-102.

Orlitzky, M., Siegel, D., \& Waldman, D. (2011). Strategic Corporate Social Responsibility and Environmental Sustainability. Business and Society, 50(1), 6-27.

Parasuraman, A., Berry, L., \& Zeithaml, V. (1991). Perceived Service Quality as a Customer-based Performance Measure: An Empirical Examination of Organizational Barriers Using and Extended Service Quality Model. Human Resource Management, 30(3), 335-364.

Petrick, J. F. (2002). Development of a Multi-Dimensional Scale for Measuring the Perceived Value of a Service. Journal of Leisure Research, 34(2), 119.

Prabhakar, G., Diab, W., \& Bhargavi, S. (2016). Transformational Leadership and Corporate Social Responsibility: The UAE Experience. Review of Contemporary Business Research, 5(1), 108-114.

Pradhan, S., \& Pradhan, R. (2015). An Empirical Investigation of Relationship among Transformational Leadership, Affective Organizational Commitment and Contextual Performance. Vision: The Journal of Business Perspective, 19(3), 227-235.

Ramasamy, B., \& Yeung, M. (2009). Chinese Consumers' Perception of Corporate Social Responsibility (CSR). Journal of Business Ethics, 88, 119-132.

Robbins, S. P., \& Judge, T. A. (2015). Organizational Behavior. Pearson.

Saeidi, S., Sofian, S., Saeidi, P., Saeidi, S., \& Saaeidi, S. (2015). How does Corporate Social Responsibility Contribute to Firm Financial Performance? The Mediating Role of Competitive Advantage, Reputation, and Customer Satisfaction. Journal of Business Research, 68(2), 341-350.

Schwaiger, M. (2004). Components and Parameters of Corporate Reputation-An Empirical Study. Schmalenbach Business Review, 56, 46-71.

Sekaran, U., \& Bougie, R. (2016). Research Methods for Business: A Skill Building Approach. John Wiley and Sons.

Shahhosseini, M., Silong, A., \& Ismaill, I. (2013). Relationship between Transactional, Transformational Leadership Styles, Emotional Intelligence and Job Performance. Researchers World, 4(1), 15.

Shahin, A., Naftchali, J., \& Pool, J. (2014). Developing a Model for the Influence of Perceived Organizational Climate on Organizational Citizenship Behaviour and Organizational Performance Based on Balanced Score Card. International Journal of Productivity and Performance Management, 63, 290-307.

Simpson, W., \& Kohers, T. (2002). The Link between Corporate Social and Financial Performance: Evidence from the Banking Industry. Journal of Business Ethics, 35(2), 97-109.

Sosik, J., \& Jung, D. (2011). Full Range Leadership Development: Pathways for People, Profit and Planet. Taylor and Francis.

Talaei, G., \& Nejati, M. (2008). Corporate Social Responsibility in Auto Industry: An Iranian Perspective. Lex ET Scientia International Journal (LESIJ), (XV-1), 84-94.

Tavakkol, M., \& Janani, H. (2014). The Relationship between Transformational Leadership and Job Satisfaction. International Journal of Sport Studies, 4(12), 1565-1569.

Tseng, S., \& Lee, P. (2014). The Effect of Knowledge Management Capability and Dynamic Capability on Organizational Performance. Journal of Enterprise Information Management, 27(2), 158-179.

Turner, N., Barling, J., Epitropaki, O., Butcher, V., \& Milner, C. (2002). Transformational Leadership and Moral Reasoning. Journal of Applied Psychology, 87(2), 304.

Veríssimo, J., \& Lacerda, T. (2015). The Impact of CEOs' transformational Leadership and Ethical Integrity on Strategic Orientation to Corporate Social Responsibility. Portuguese Journal of Management Studies, 20(2), 95-114.

Waldman, D., Siegel, D., \& Javidan, M. (2006). Components of CEO Transformational Leadership and Corporate Social Responsibility. Journal of Management Studies, 43(8), 1703-1725.

Wang, Q., Wu, C., \& Sun, Y. (2015). Evaluating Corporate Social Responsibility of Airlines using Entropy Weight and Grey relation Analysis. Journal of Air Transport Management, 42, 55-62. 
WBCSD (1999), Corporate Social Responsibility, World Business Council for Sustainable Development.

West, S., Finch, J., \& Curran, P. (1995). Structural Equation Models with Non-Normal Variables: Problems and Remedies. In R. H. Hoyle (Ed.), Structural Equation Modeling: Concepts, Issues, and Applications (pp. 5675). Thousand Oaks, CA: Sage Publications.

Wheelen, T., Hunger, J., Hoffman, A., \& Bamford, C. E. (2015). Strategic Management and Business Policy: Globalization, Innovation, and Sustainability (14th Ed). Pearson.

Yee, R., Yeung, A., \& Cheng, T. (2010). An Empirical Study of Employee Loyalty, Service Quality and Firm Performance in the Service Industry. International Journal of Production Economics, 124(1), 109-120.

Yong, A., \& Pearce, S. (2013). A Beginner's Guide to Factor Analysis: Focusing on Exploratory Factor Analysis. Tutorials in Quantitative Methods for Psychology, 9(2), 79-94.

\section{Copyrights}

Copyright for this article is retained by the author(s), with first publication rights granted to the journal.

This is an open-access article distributed under the terms and conditions of the Creative Commons Attribution license (http://creativecommons.org/licenses/by/4.0/). 